\title{
Datos para una biografía del jurista Pedro Murillo Velarde y Bravo ${ }^{1}$
}

\author{
LUIS DIAZZ de La GuARDia y LÓPEZ ${ }^{2}$
}

\begin{abstract}
RESUMEN
ABSTRACT

En el presente artículo se pretende aportar una serie de coordenadas para fijar la vida y el pensamiento de Pedro Murillo Velarde y Bravo (Laujar 1696-Puerto de Santa Maria 1753).

Hidalgo de familia de caballeros, sobrino de un Obispo de Pamplona, rompe en principio con el entorno familiar de búsqueda de ascenso social para dedicarse a la misión en Filipinas, llegando a ser procurador provincial de la Compañía en Filipinas ante la Corte de Madrid y Roma. Gran jurista, historiador, geógrafo, poeta, político y orador. Por medio de documentos y obras del autor no sólo se desentraña la vida del jesuita sino también su pensamiento frente a las Filipinas, la política o la religión.

This article intends to contribute a series of coordinates to establish the life and thinking of Pedro Murillo Velarde y Bravo (Laujuar 1696-Puerto de Santa María 1753). Noble from a family of gentlemen and nephew of a Bishop of Pamplona, firstly breaks away from the family environment that seeks social promotion to dedicate himself to the mission in the Philippines, becoming the Society of Jesus'provincial representative in the Philippines before the Court of Madrid and Rome. Great jurist, historian, geographer, poet, politician and orator. Through the documents and works of the autor, not only is the life of the Jesuit unravelled but also his thinking on the Philippines politics and religion.
\end{abstract}

Al profesor doctor Alberto Carrillo Cázares, en testimonio de sincera amistad y gratitud.

2 UNED. El presente trabajo ha sido realizado dentro del proyecto de investigación del Colegio de Michoacán A.C., México, destinado a la edición en español del Curso de Derecho Canónico Hispano e Indiano de Pedro Murillo Velarde. 


\section{INTRODUCCIÓN}

Dice Michel Eyquem de Montaigne, hablando sobre la inconstancia de los hechos de los hombres y de quienes se encargan de juzgarlos y analizarlos, que "los que se ocupan de estudiar las acciones humanas se encuentran a veces muy impedidos para ajustarlas entre sí, porque es común que se contradigan de tan extraña manera que parece imposible que sean parte de una misma cosa». Por lo que concluye Montaigne afirmando que "por ello no conviene a un entendimiento asentado juzgarnos no sólo por nuestros actos exteriores, sino que ha de escudriñarse dentro y ver el móvil que los inspira" ${ }^{3}$. Desde luego a nadie se le escapa la dificultad de acercarse a la vida de una persona en concreto y más cuando ésta lleva muerta unos 250 años y perteneció a otras épocas y otras culturas, dificultad que se acrecienta no sólo al estudiarla sino al intentar traerla a nuestros días por medio de las palabras escritas para divulgar su existencia por medio de una publicación.

La bibliografía puede servir de cauce para encarrilar pretensiones como la dicha. Lo que ocurre es que en algunos casos -como en el que nos ocupa- o no existe o es muy escasa y simplemente reiterativa. $Y$ para no ser también reiterativo el que escribe, sirva de ejemplo de lo que hay lo siguiente y que aparece en la obra publicada por el C.S.I.C. gracias a su Instituto Enrique Flórez, en el año 1973, el Diccionario de Historia Eclesiástica de España —dirigido por Quintín Aldea Vaquero, Tomás Marín Martínez y José Vives Gatell (volumen tercero) - que da la siguiente aportación biográfica de Murillo Velarde:

“Sacerdote jesuita (Laujar de Andarax [Almeria] 6-VIII-1696 + Puerto de Santa María [Cádiz] 30-IX-1753) misionero e historiador. Entró en la Compañía de Jesús en 1718. Llegó a Filipinas en 1723. Profesor de Teología y Derecho Canónico en Manila, rector de colegio de Antipolo, visitador de las misiones de Mindanao, procurador en Roma y Madrid" 4.

\footnotetext{
3 M.E. de Montaigne, Ensayos. Editorial Orbis, Barcelona 1984, tomo II, pp. 7 y 12.

4 Completada con la siguiente nota bibliográfica: OBRas: Historia de la provincia de Philipinas de la Compañia de Jesús. Manila 1749; Corpus luris canonici hispani et indici. Ma. 1743; Geographia historica, 10 vols., Ma. 1752. Bıb.: N. Southwel, Bibliotheca Scriptorum S.I., Ro. 1950-51, V, 1455-59, y XII, 1283; H. de la Costa, The Jesuits in the Phiippines 1581-1768. Cambridge Mass, 1961, 691; B. Sánchez Alonso, Historia de la Historiografía Española. 3 vols., Manila, 1941-50, III 171-72.
} 
Para lo que se acaba de leer se utilizó a N. Southwel, Bibliotheca Scriptorum S.I. (Roma 1676) y H. de la Costa The Jesuits in the Philippines 1581-1768, (Cambridge, Mass, 1961). Lo citado -como en obras similares del $\mathrm{XIX} 0$ anteriores- da referencias biográficas que no exceden del panegírico de Bernardo Pazuengos ${ }^{5}$. Por lo que respecta a su producción bibliográfica, la descripción más completa que se ha hallado hasta ahora es sin duda la de $\mathrm{C}$. Sommervogel y su Bibliothèque de la Compagnie de Jésus (1890-1900), que se nutre, para Pedro Murillo, de repertorios bibliográficos hispanos.

En definitiva en las obras notables de referencia más bien poco. Pero es que desde el campo de la historiografía más reciente vertida en artículos o introducciones tampoco hay mucho que destacar. Quizá sea el primero que lo trata científicamente y con cierta profundidad - dejando a un lado a Menéndez Pelayo- el erudito Ángel del Arco Molinero en su «Estudio biográfico-bibliográfico del canonista fray (sic) Pedro Murillo Velarde", publicado en 1901 en la Revista de Archivos, Bibliotecas y Museos (3. ${ }^{a}$ época), V, pp. 367-376, trabajo que aparentemente no tuvo un seguimiento en otras obras sobre Murillo. Durante mucho tiempo se siguen teniendo como válidas pequeñas reseñas o menologios, todos repetitivos en cuanto a fuentes y contenido. Será después de los años 80, en España, cuando empiecen a aparecer obras que se acercan a Pedro Murillo, pero en sentido oblicuo, no directo. Se quiere decir que se le estudia más en relación con su obra que con su vida per se, tal es el caso de por ejemplo la comunicación presentada al Congreso de Historia del Descubrimiento en 1992, cuya autora es Isabel Rodriguez Macías, titulada «El descubrimiento y la conquista en un cronista andaluz del siglo XVIII: Pedro Murillo Velarde", y recogida en el tomo IV de las Actas de dicho encuentro, publicadas en el 92, en las pp. 357-387. Anteriormente la Universidad de Granada también hizo aproximaciones a Murillo - granadino por mucho tiempo olvidado-, publicando dos obras que son extractos de la obra murillense Geografía Histórica. Concretamente en 1988, con una introducción de Ramón María Serrera y María Ángeles Gálvez, se publica en Granada por la Biblioteca de la Cultura Andaluza la obra Geographia de Andalucía (1752). Igualmente por el profesor granadino Serrera y con prólogo del académico español Antonio Domínguez

5 P. B. PAZUengos, Carta edificante sobre la vida, virtudes y muerte del p. Pedro Murillo Velarde, religioso de la Compañia de Jesús. Nicolás Villargordo y Alcaraz, Murcia, s.a. 
Ortiz, se edita por la Universidad de Granada en 1990 Geographía de América (1752). Últimamente, en la ciudad jiennense de Alcalá la Real se ha presentado una comunicación en el XV Congreso de Profesores e Investigadores, titulada «Alpujarreños en Filipinas: Pedro Murillo-Velarde", cuyo autor es Carlos Villoria Prieto. Las Actas de este Congreso no han sido aún editadas, en las fechas que estas páginas se escriben. No obstante todos los trabajos citados, excepto el de del Arco Molinero, no aportan nada realmente significativo, de hecho no hay casi investigación de fuentes primarias. Sigue siendo guión pleno el discurso de Pazuengos y poco más.

En cuanto a obras de fuera de España, destacar dos, una primera publicada en Chile por Hugo Hanisch Espíndola en la Revista Chilena de Historia del Derecho, 12 (1986), titulada "Pedro Murillo Velarde S.J., canonista del siglo XVIII. Vida y obras", la obra se trae aquí no por sus aportaciones que presentadas como novedosas son ya un poco rancias, sino como aviso a caminantes, pues no deja de ser un trasunto -en ocasiones, demasiadas, totalmente textual- de la referida obra de Ángel del Arco Molinero, publicada en 1901. En el otro extremo, aunque no es una obra monográfica sobre Pedro MuriIlo Velarde, sino que su vida, obra y pensamiento están dispersos en las páginas del libro, se encuentra la realizada por $\mathrm{p}$. $\mathrm{H}$. de la Costa, nombrada The Jesuits in the Philippines 1581-1768, (Cambridge, Mass, 1961), y desde luego puede calificarse ésta como la más seria y completa de la publicadas sobre los jesuitas en Filipinas y dentro de ella la que más profundiza - pese a lo dicho- en Pedro Murillo Velarde, intentando superar lo anterior y con valores de verdadera obra científica.

No quedaba otro remedio en consecuencia que zambullirse en $\mathrm{Ar}$ chivos -lo que por cierto no es algo antipático para el autor- en busca de completar cosas, de añadir otras y sobre todo en busca de la vida y el pensamiento, del desarrollo vital en suma, del personaje investigado. Archivos que, por la andariega y desconocida vida de Pedro Murillo Velarde, debieron ser muchos: Archivo de Roma de la Compañía de Jesús, General de Indias, Archivo Histórico Nacional de Madrid, Archivo de la Real Chancillería de Granada, Archivo Histórico Provincial de Almería, Archivo de la Universidad de Salamanca, Archivo de la Universidad de Granada, Archivo Notarial de Granada, Archivo de la Provincia de Toledo de la Compañía de Jesús, Archivo de la Curia de Granada, etc. 
Con todo lo dicho se pretende ahora acumular datos y opiniones, unos totalmente nuevos y otros que ya fueron dados a conocer en parte por otros o por el que escribe en diversos seminarios y reuniones de trabajo que desde el año 1999, cuando menos, se han venido organizando en el Centro de las Tradiciones del Colegio de Michoacán, A.C., (México), en la ciudad michoacana de Zamora. No se dilate más el discurso introductorio y comiéncese con la tarea de conocer un poco más a Pedro Murillo Velarde.

\section{LA FAMILIA DE PEDRO MURILLO-VELARDE Y BRAVO}

Si el francés Montaigne recomienda no sólo conocer a las personas sino intentar comprenderlas resulta imprescindible saber someramente quiénes eran estos Murillo a los que pertenecía don Pedro. La razón es clara, ya que las tradiciones familiares y el entorno paterno-filial en donde transcurren los primeros años de una vida marca intensamente a ésta. No obstante, no se trata de desarrollar un discurso genealógico sino de ver qué líneas marcaban la familia del jesuita Murillo. Una de ellas sin duda será la conciencia de su rancia sangre y de su condición de cristianos viejos e hidalgos dedicados a labranzas, negocios especulativos y acaparación de poder.

Los Murillo Velarde del Reino de Granada procedían de la villa de Campanario en la actual provincia de Badajoz, partido judicial de Villanueva de la Serena. Alí, en Extremadura, residían los más linajudos del apellido Murillo o Morillo -que lo mismo da- y alli el 6 de junio de 1583 en contradictorio juicio con la Real Chancillería de Granada obtuvieron el reconocimiento de su hidalguía Juan Morillo y Rodrigo Morillo, vecinos de esa villa, y antepasados directos de los Murillo estudiados ${ }^{6}$. No obstante, no fueron los únicos en ver reconocida su nobleza por el alto tribunal granadino, de igual modo conseguian ejecutoria o una provisión de hidalguía en la Chancillería de Granada los siguientes: Juan y Antón Donoso Murillo que ganaron Real Provisión en Campanario en 1681 , siendo vecinos de esa villa. De la misma localidad, los hermanos Murillo Valdivia pleiteaban su nobleza en 1726. Otro del mismo linaje lo hacía en Puebla de la Reina en 1785: Fer-

\footnotetext{
6 Archivo de la Universidad de Granada (desde ahora A.U.G.), Libro 11, fol. 266.
} 
nando Murillo Valdivia. En la Haba en 1738 Andrés Murillo Velarde. Rodrigo Murillo Velarde en Zalamea de la Serena en 1713. En Siruela ganan el 29 de agosto de 1659 real carta ejecutoria de hidalguía los hermanos Bautista y Francisco Murillo Villalobos. Pero es que además, ya en el siglo XIX un descendiente de los Murillo de Laujar, llamado Luis Murillo, siendo vecino de Berja entre 1802 y 1809 obtendrá reales provisiones de estado en donde se le confiere el reconocimiento de su nobleza.Y es que como dice el padre Pazuengos hablando de esta familia de Murillo:

"Perfeccionada la conquista, fue ilustrado aquel obscuro ángulo con el esplendor de la sangre de los vencedores, y enriquecidos y heredados estos para siempre con los despojos, tierras, casas y arbolados de los rebeldes, dos vezes infames. Infames por el crimen de Lesa Magestad e infames por su agarena raza. A esta gloriosa conquista vinieron Pedro y Juan Murillo Velarde, éste hijo y aquél padre, con otros adalies exforzados del mismo apellido ilustre y exclarecida sangre, del dilatado, rico y fertilísimo Quartel o Partido de la Serena, en la gran provincia de Extremadura vaxa. Partido tan poblado de nobleza antigua, pura y acendrada que aunque todo su dilatado suelo es una casi planicie, se llama la Nueva Montaña. En este país tan inundado de nobleza, hacen (de inmemorial) mucho viso el tronco y ramas de Murillo Velarde. Gozando siempre (sin que memoria pueda alcanzar lo contrario) todos los actos positivos de nobleza, que forman el respetoso charácter de Cavalleros Hijos de Algo. Sin que gloria tan estimable a los ojos del mundo se haya visto jamás anublada, y menos interrumpida, ni en la generosa estirpe, ni en alguna de sus ramas. Así en la provincia de Estremadura como en los Reinos de Córdova y Granada. Logrando en todas partes iguales enlaces a su prosapia ilustre con los Ocañas, Contreras, Peñafieles, Ovandos, Mendozas, etc. $Y$ contando pendientes de su tronco y ramas (en paz y en guerra) todos aquellos blasones de gloria que puede apetecer o invidiar la ambición más alta"?

Uno de los hijos de Juan Murillo, llamado Pedro Murillo Velarde, sargento mayor de la Gente de Guerra que vino a las Alpujarras, se trasladó a ellas y al Reino de Granada por las alteraciones de los moriscos de 1569. Pero no vino sólo, sino que le acompañaba que se sepa su hijo Juan Murillo Velarde, y ambos originarios del partido de la Serena en Extremadura. Los cuales una vez dominada la revuelta y expulsados los moriscos recibieron suertes de tierra y población en las

P. B. Pazuengos, Carta edificante, cit., pp. 21-23. 
Alpujarras. Tomada la localidad de Laujar de Andarax -en el Reino de Granada, en sus Alpujarras orientales- como el nuevo solar de los Murillo Velarde, estos empezaron a ser tratados como hidalgos que lo eran - aunque modestos - y a ocupar cargos concejiles de honra así como a dedicarse a sus labranzas ${ }^{8}$.

Poco a poco la familia se fue fortaleciendo con enlaces y con nuevas rentas, de este modo ya disponía de un capital aceptable en Laujar, el hijo de Juan Murillo, llamado Pedro Murillo Velarde que casó en Laujar con Doña Ana López de Maior, y que disfrutó en reiteradas ocasiones la alcaldía ordinaria y la regiduría de su pueblo natal ${ }^{9}$. En su villa de Laujar moría Pedro Murillo Velarde - siendo enterrado en la capilla de los López de Mayor-, el cual había hecho testamento, viudo ya, el 31 de diciembre de 1662 ante el escribano Diego de Salazar ${ }^{10}$. En este documento consta que fueron sus hijos - que superaron la edad pupilar-: Juan Morillo, doña María Morillo, don Pedro Morillo, Antonio y Bernardo Morillo Belarde y López de Mayor. La mayoría de

B Pedro Murillo Velarde describiría Laujar en su Geografía, en la parte dedicada a Andalucia, de la siguiente forma: "Laujar es uno de los pueblos más principales, en los mapas lo ponen con el nombre antiguo de Andarax, que significa Era de la Vida, por lo delicioso y alegre de aquel sitio; es muy abundante de frutas, de trigo, cebada, maiz, cáñamo, lino, mijo, centeno, aceite, seda, vino, higos, almendras, limones, naranjas y otros frutos; legumbres y hortalizas. Tiene bastante ganado de lana, de que se hacen buenos paños. Hay pescado regalado y caballos generosos. Coge parte de la Sierra Nevada, y una vega llana, hermosa y abundante, que la fertiliza el riego de la mucha y hermosa agua que hay. Tiene un río mediano; muchas fuentes, arroyos y acequias; muchas arboledas y huertas; el cielo es alegre. Tiene una fábrica de paños que se llevó de Alcoy. Cuando la rebelión de los moriscos, padecieron los cristianos de este pueblo gran persecución y muchos dieron sus vidas por Cristo; y alli se conserva un paraje que llaman "el aljibe de los mártires", por los muchos cristianos martirizados que alli padecieron. Un libro hay impreso de los muchos cristianos martirizados en las Alpujarras. Hay en este pueblo dos compañías para la defensa de la costa y reino de Granada", P. Murillo Velarde, Geografía Histórica, apud A. Puertas GarCIA, Laujar de Andarax en el siglo xvII. I.E.A., Granada, 1991, p. 19.

9 Por ejemplo en carta de poder otorgada por el concejo de la villa de Laujar ante el es cribano Mérida relativo a la renta de la Sal aparece Pedro Murillo Velarde como alcalde ordinario: «En la villa de Lauxar de las Alpuxarras, a veynte y cinco dias del mes de enero de mil y seisçientos y cinquenta y un años, ante my el escribano y testigos, pareçieron Pedro MoriIlo Belarde y Gabriel de Salazar, alcaldes, y Juan Rodríguez de Valdivia y Françisco Gómez de Mercado, rexidores...", en Archivo Notarial de Granada, (desde ahora A.N.G.), Protocolos, Ugijar, 1760-51, escribano Mérida, sin foliar.

10 "En el nonbre de Dios nuestro Señor y de la Birgen Santa María, su madre, sepan quantos esta carta de testamento y última y final boluntad vieren como yo Pedro Morillo $\mathrm{Be}$ larde, vezino de esta villa de Lauxar de Andarax, viudo de doña Ana López mi muger, difunta...", Archivo Histórico Provincial de Almería (A.H.P. A.), Protocolos, p. 1444, fol.490-494v. ${ }^{\circ}$. 
ellos tendrían descendencia. De este modo Juan Murillo -o MorilloVelarde y López de Mayor otorgaría carta de dote y arras a favor de doña María de Escalona y Arias, hija de Pedro Rodríguez Arias y de doña María de Escalona. La escritura está fechada el 19 de enero de 1669 y fue hecha ante Diego de Salazar, escribano, y los testigos Gabriel López de Mayor, Luis Moreno y Cristóbal López de Mayor ${ }^{11}$. La futura esposa aportó como bienes dotales la cantidad de 10.935 reales, y le fueron entregados como arras por Murillo unos 2.200 reales, mientras que el capital del último era de 20.926 reales. También su hermano Francisco Murillo Velarde y López de Mayor capitulaba su dote y arras con doña Urbana de Salazar y Zéspedes, hija de Francisco y de doña Ana Margarita, por un valor de 20.000 reales, más 2.200 en concepto de arras. Todo se hizo ante el pariente de la novia Diego de Salazar, escribano, el 6 de abril de 1669, y los testigos Bernardo Gómez de Valdivia, Pedro de Mercado y Gaspar Cortés ${ }^{12}$.

Igualmente hijo de Pedro Murillo Velarde y de doña Ana López de Mayor, fue don Pedro Murillo Velarde y López de Mayor, que fue bautizado en Laujar de Andarax el 23 de febrero de 1644. Gracias a su padre - que apenas sabía dibujar su firma- el joven Pedro Murillo Velarde y López de Mayor se inició en las letras y llegada su edad correspondiente marchó a Granada a estudiar la carrera de leyes en la que se licenció. De hecho ya estaba estudiando en Granada en 1662, como consta en una cláusula del testamento paterno en la que se recoge que: "es mi boluntad que si mi hijo don Pedro Morillo, que al presente está estudiando en la ziudad de Granada, llegara a ordenarse de orden sacro, se le dé para hazer patrimonio para que se ordene mil ducados" ${ }^{13}$. Pero no fueron por la religión los derroteros vitales de don Pedro Murillo Velarde sino por la vida seglar y en matrimonio. $Y$ además, hay que decir, que su actividad profesional fue relativamente satisfactoria: de simple abogado de la Real Chancillería de Granada pasaría a convertirse en letrado de los Reales Consejos. De igual modo adquirió el goce de determinados cargos de corte político-administrativo y judicial. Fue alcalde ordinario y regidor de la villa de Laujar, Alcalde Mayor de Almuñecar, Procurador General del Partido de las Alpujarras, Auditor de la Gente de Guerra de la villa de Adra, Juez de

Ibidem, fol. 182-184.

lbidem, fol. 204-207.

Ibidem, fol. $490-494 v{ }^{\circ}$. 
Tercias y Alcabalas de Laujar, Fondón y Benecid, Provisor del Obispado de Badajoz y Auditor General por Su Majestad del Socorro de la Costa del Reino de Granada ${ }^{14}$.

Pero su vida profesional, destinada al servicio del Rey, le hizo viajar por diferentes zonas de Andalucía, teniendo su hogar en otras villas además de Laujar. Por ejemplo al ser nombrado auditor del Reino de Granada, pasó a vivir a la ciudad de Vélez Málaga, lo que también le ocurrió al licenciado y abogado de la Real Chancillería de Granada, don Bernardo Gómez de Mercado y Calderón, que por ese tiempo fue designado auditor de la Gente de Guerra de Almería, donde localizó su solar, y que estaba casado con doña Antonia de Ocaña Mercado y Corbera, pariente de la mujer de don Pedro Murillo Velarde ${ }^{15}$. Esta brillante carrera - dentro de unos límites- hizo elevarse a su familia y permitió que ésta soñara con más altos destinos. Destinos que se cumplieron en su hijo Andrés Obispo de Pamplona y en sus nietos, hijos de su otro hijo Jacinto y padre del jesuita Pedro Murillo Velarde y Bravo. Volviendo a su progenitor, el licenciado don Pedro Murillo Velarde casaría en Laujar el 29 de septiembre de 1666 con Doña María de Ocaña y Contreras, bautizada en Laujar el 23 de agosto de 1645, siendo hija del que fuera alcalde ordinario y regidor de Laujar, Jacinto Fernández de Ocaña y de su mujer legítima Doña María de Contreras. Dotó Pedro a María de Ocaña en Laujar el 9 de septiembre de 1666 por una cantidad de 71.600 reales y 22.000 reales de arras, siendo testigos Pedro Sánchez de Mercado, Diego de Castañeda y Juan Murillo ${ }^{16}$. Este

\footnotetext{
14 Ibidem, Protocolos, p. 1482, fol.11.

15 Archivo de la Curia de Granada, (desde ahora A.C.G.), Leg.70, F(6), sin foliar.

16 «En el nonbre de Dios, nuestro Señor, y de la Virgen, nuestra Señora. Sepan quantos esta carta de dote y arras bieren como yo Don Pedro Antonio Murillo Velarde, hijo lejítimo de Pedro Murillo Belarde y de Doña Ana López, su mujer, ya difuntos, veçinos que fueron de esta villa de Laujar. Digo que por quanto para serbizio de Dios nuestro Señor, y con su grazia y bendizión yo estoi tratado de que me he de casar sigún orden de la Santa Madre Iglesia con Doña María de Ocaña Contreras, donzella, hija lijítima de Jacinto Fernández de Ocaña, vezino de esta villa de Laujar, y de Doña María de Contreras, ya difunta. Y por quanto se trató el dicho casamiento se me mandaron con la susodicha algunos bienes y caudal para ayudar a sustentar las cargas del matrimonio y porque a oi me quiero desposar y belar con la susodicha y rezibir las bendiziones nuziales. $Y$ para que en todo tienpo consten los bienes que rezibo de mano del dicho Jazinto Fernández, para en quenta de la lijítima materna de la dicha mi esposa otorgo por esta carta que en la mejor forma que a lugar en Derecho rezibo los bienes que son declarados, tasados a mi satifazión por personas que de ello entienden en la manera siguiente: Primeramente tres colchones de lienzo de lino con sus henchimientos de lana que tienen treinta y siete baras de lienço a seis reales cada bara, que el dicho
} 
matrimonio -el de Pedro Murillo y Doña María de Ocaña - moriría en su villa natal y serían enterrados en la capilla que les pertenecía en la Iglesia Parroquial, donde estaban sus armas, y de la que eran poseedores por la rama de los Ocaña. Esta capilla la adquirió Jacinto Fernández de Ocaña a su familia política los Beltrán y Corvera, a los cuales pertenecía su muger doña María de Contreras. Señora que testaría en Laujar de Andarax el 3 de julio de 1647, dejando por herederos universales a sus dos hijas doña María de Ocaña y Contreras y doña Francisca de Ocaña Mercado y Corvera, y como albaceas testamentarios a su marido Jacinto y a su tío Juan Sánchez Nieto ${ }^{17}$. La escritura se efectuó ante el escribano de la villa Diego de Salazar, siendo testigos Martín Arias, Jaime de Fuentes, Diego Rodríguez, Simón Alonso y Gaspar Cortés, todos vecinos del lugar.

Si los Murillo estaban orgullosos de su nobleza y decididos a acrecentarla, el linaje materno de Pedro Murillo Velarde, el de Bravo, no les iba a la zaga. Linaje, también éste, con ejecutorias de hidalguía en la Chancillería de Granada y Valladolid, y que se asienta en las Alpujarras, concretamente en el Presidio tras la Guerra y Rebelión de los Moriscos. Siendo oriundos en un principio del lugar de Sotronca, en Lodoso, Valle de la villa de Santibáñez - Merindad del Campó- en las Montañas de Burgos de donde pasó el capitán Bravo de Henestrosa. Capitán que murió en la mencionada guerra en 1568. Pero antes había tenido por hijo al capitán Juan Bravo de Henestrosa y del Río, quien casó con Doña Francisca Morales, hija del capitán y gobernador del Presidio de Adra, que también moriría en la sublevación referida en $1568{ }^{18}$.

Transcurridos los años, el 6 de septiembre de 1697, testaba en Laujar el antiguo corregidor del Toboso el licenciado don Vicente Bravo de Henestrosa y Mercado, hijo de otro Lázaro Bravo - regidor perpe-

lienzo monta dozientos y beinte y zinco reales... Unos zarzillos de oro basquillo en ziento y zinquenta y dos reales... La suerte que dizen de la Balsa son sesenta y seis arrobas de hoja de moral que tiene dentro a treinta reaies cada arroba y la tierra de dicha suerte doze barchetas, a trescientos y treinta reales cada barcheta, morita todo zinco mil nuebezientos y quarenta reales... Una casa mesón en esta villa y barrio de la plaza, linde la calle real y casas de Pedro Busnuezo y la callejuela que sube al mesón de arriba en zinco mil y quinientos reales...", A.N.G., Protocolos, Ugijar 1666, escribano Juan Fernández de Valdivia, fol. 129-132.

17 A.H.P. A., Protocolos, p. 1443, fol.128-130.

18 P. Murillo Vel.ARDE, Geographía de América. Edición de R.M. Serrera Contreras, Universidad de Granada, Granada, 1990, estudio preliminar. 
tuo y alcalde provincial de la Santa Hermandad de Paterna- y de doña Isabel Gómez de Mercado y Calderón. Cabeza, el licenciado Vicente Bravo de Hinestrosa y Mercado, de los Bravos alpujarreños, no sólo contaba en su casa con gran número de documentos sobre la nobleza de su familia ${ }^{19}$, sino que era persona muy preocupada con esta condición nobiliaria, como se trasluce de la siguiente cláusula de su testamento:

"mando que por quanto don Vizente Brabo, mi terzero abuelo paterno y su muger fueron descendientes de las Montañas de Burgos, y el susodicho fue martirizado por los moriscos rebeldes de Paterna y dicha su muger cautiva asta que fue puesta en libertad por los exérzitos christianos. $Y$ tubieron repartimientos y grandes haciendas de conquistadores y pobladores como otros ascendientes míos,..., es mi boluntad que el dicho don Lázaro mi hijo y sus descendientes conserben en las casas de su morada el escudo de armas de dicha casa. Que son de un árbol dos perros atados a su tronco, en abandera dos cavezas, cinco calderas, tres estrellas y tres varas de las quales sale una mano y el apellido de Borja junto con el Brabo» 20.

Por lo tanto Pedro Murillo venía al mundo en una familia de la pequeña nobleza provinciana, cuyos miembros, muy conscientes y orgullosos de ello, estaban dispuestos en virtud de sus economias a desarrollar un ascenso social en beneficio propio y de sus descendientes. $\mathrm{Y}$, geográficamente, pese a tener su solar en las lejanas sierras de Granada, de difícil acceso, lo cierto es que la capital del reino, la bella ciudad de Granada, podía por sus circunstancias ser un buen disparadero para ambiciones con ciertas apoyaturas. Pues, como dicen Cortés Peña y Bernard Vincent, la universidad, la Chancillería, el concejo y la Iglesia, todas estas instituciones, junto a otras, "presentaban en su estructura y en su mismo dinamismo una completa imbricación con la vida ciudadana, dando lugar a que el perfil de Granada nos aparezca

19 Como él mismo dice en su testamento: «los quales dichos mis ascendientes conquistadores de este Reino, tengo escritos sus nonbres y apellidos en árbol genealógico que se hallará entre mis papeles... todo lo qual to pongo aquí para declarazión de mis lineas y ascendientes y descendientes para la claridad y que en todo tienpo conste del parentesco y derecho que mis hijos tienen a los vínculos y maiorazgos que son llamados y consta de esta declarazión", en A.H.P. A., Justicia, J.70, fol. 7-7v. , o que "declaro que los papeles de nobleza de mi familia, posesión de mitad de ofizios de tubimos en la villa de Paterna por el apellido Bravo y los demás instrumentos que a esto conduzen están y se hallarán en un arca de mi casa", Ibidem, fol. 7v. .

20 lbidem, fol 10. 
de forma nítida como el correspondiente al de una ciudad típicamente burocrática, en la que las actividades administrativas y judiciales, aún sin ser exclusivas, marcaban sus funciones principales" ${ }^{21}$. La oportunidad iba a ser aprovechada por Pedro Murillo Velarde y por casi toda su familia más cercana.

Hablando de ésta, de la familia cercana se debe decir que a finales del siglo XVII y comienzos del siglo XVIII vivieron en la villa de Laujar los padres del protagonista de este estudio. Estos no eran otros que don Jacinto Murillo-Velarde y Fernández de Ocaña y doña Magdalena Bravo y Valdivia. Familia de hidalgos labradores en las tierras alpujarreñas y que además siguió en su empeño de acaparar cargos de la administración regia pese a que fuera en menor grado que lo había hecho su padre, el licenciado Pedro Murillo Velarde. Ya que, aunque dividida la herencia de sus hacedores, lo cierto es que los hijos del licenciado Pedro Murillo gozaron de una buena fortuna con la que reforzar sus carreras. Y es que el licenciado Pedro Murillo Velarde era dueño de tierras, casas, esclavos, criados y de muchas comodidades y contactos políticos. Administraba además los capitales de algunos parientes como el de su cuñada doña Gabriela de Ocaña ${ }^{22}$, por todo lo cual podía dejar un buen capital a sus hijos y herederos.

El padre del canonista y jesuita, don Jacinto Murillo Velarde, nace en Laujar — fue bautizado en su Parroquia el 26 de agosto de $1667^{23}$ _,

21 A.L. Cortés Peña y B. VInCENt, Historia de Granada III, la época moderna. Siglos XVI, $x$ x' y xvil. Editorial Don Quijote, Granada, 1986, p. 300.

22 Así consta, por ejemplo, de la siguiente escritura de venta otorgada en Laujar ante el escribano Diego de Salazar el 30 de octubre de 1676: "Sepan quantos esta carta de benta bieren, como yo el lizenziado don Pedro Morillo Belarde, vezino de esta villa, como tutor y curador de la persona y bienes de doña Gabriela de Ocaña, vezina de esta villa, mi menora y mi cuñada: otorgo y conozco que bendo, zedo, renunzio y traspaso al lizenziado don Bernardo Gómez de Mercado, benefiziado del lugar del Presidio, un esclabo que la dicha mi menor tiene y le tocó en la partizión que se hizo por muerte de doña Maria Sánchez y Corbera, difuncta, su madre. El qual dicho esclabo se llama Juan de la Cruz de edad de hasta beynte y dos años, herrado entre las dos zejas, de color blanco. El qual le bendo por sujeto a serbidumbre y con todas sus tachas buenas o malas, manifiestas o encubiertas, $v$ por prezio $y$ contía de dos mil y ochozientos reales que por el balor del dicho esclabo confieso aber rezebido de mano del dicho comprador", A.H.P. A., Protocolos, p. 1445, fol.121-121v. ${ }^{\circ}$.

23 «En veinte y seis de agosto de seisçientos y sesenta y siete el Liçençiado Don Manuel Méndez de Castro, de mi lizenzia, babtizó a Jaçinto Laurençio, hijo de Don Pedro Murillo y de Doña María de Contreras, su muger. Padrinos, Jaçinto Fernández de Ocaña y Doña María de Mercado su muger. Testigos, Diego de Salazar, Françisco de Grazia y Françisco Gómez. Todos mis feligreses», A.U.G. Registro de pruebas del Colegio de Santa Cruz, Exp. 4, fol. 197-197v. . 
actual provincia de Almería, pero en su tiempo perte .. ziente al Reino de Granada y con una más estrecha relación con su capital, la ciudad de Granada. Su vida en principio se centrará fundamentalmente allí. En Laujar poseía sus labranzas y allí desempeñó cargos municipales reservados a las familias más distinguidas de la zona. De este modo sería regidor perpetuo de la localidad del Presidio de Adra, provincial de la Santa Hermandad e igualmente será en diversos años alcalde ordinario y regidor añal de su villa natal, Laujar, y capitán de una de las compañías de Infantería de las Alpujarras, con la que participó como noble - como cuenta en su testamento- en la guerra de Sucesión española a favor de Felipe $V$. Su carrera honorífica alcanzaría su cénit al ser nombrado comisario general del Partido de las Alpujarras.

En la localidad del Presidio, donde era regidor, casaria el 22 de abril de 1685 con doña Magdalena Bravo y Valdivia, hija del regidor perpetuo del Presidio don Matías Bravo, natural de la villa alpujarreña de Paterna, y de doña María de Valdivia, natural del Presidio. Era además Patrono de la Capellanía que fundaron sus padres de la que fue primer capellán Andrés Murillo Velarde, su hermano. Muy unido a éste, a su hermano el futuro obispo Andrés, le ayudaría en numerosas ocasiones para que - antes de convertirse en prelado- pudiese llevar a cabo su carrera. Corroborándolo, en el testamento de don Jacinto se dice que:

"Declaro que a don Andrés Murillo, mi hermano, e asistido con diferentes porçiones de maravedís en asistençias que le e echo en las pruebas que se hiçieron para Collegial Mayor del Collexio de Cuenca de la Unibersidad de Salamanca, para Canónigo de Badaxoz, para Canónigo de Murçia y para Canónigo de Toledo, de lo qual tenemos cuenta muy larga» ${ }^{24}$.

Don Jacinto se encontraba inserto -como se infiere de la ocupación de oficios en su desarrollo vital- en una carrera por el ascenso social que muchos de su familia habian seguido. De tal modo - que como en otros linajes de la época- esta carrera condiciona y caracteriza al grupo de parientes. Todo esto era necesario no sólo para mantener una parcela de poder que les permitiera avanzar en la escala social sino que también facilitaba a aquel, que estuviera dispuesto, a disfrutar de una serie de comodidades y lujos muy alejados del común

${ }^{24}$ A.H.P. A., p. 1482 , fol. 13. 
denominador de la inmensa mayoría de la población. Esto ocurre en la casa de don Jacinto y doña Magdalena Bravo padres del jesuita Pedro Murillo. Cuadros, espejos, cuberterías de plata, buenos muebles, alfombras, una o varias casas principales, capillas y enterramientos, etc., permitían a sus poseedores una vida regalada, dentro de sus posibilidades. Además en la casa paterna de Pedro Murillo Velarde y Bravo se respiraba un ambiente de cierta cultura más relevante de lo común en esas fechas, ambiente que seguramente se inició ya en tiempos de su abuelo el licenciado Pedro Murillo-Velarde. Este ambiente cultural tiene su muestra más evidente en la colección de libros que se alojaba en la casa de don Jacinto, al igual que en mapas o cuadros no sólo religiosos sino también de temas clásicos.

Poseían una biblioteca ciertamente con más libros religiosos que de otro tipo pero acompañados no en mucho menor número por obras de los más diversos contenidos: históricos, poéticos, novelísticos o de teatro, geografía, matemáticas o mitología. Más de sesenta y dos libros se encontraban reunidos en la noble casa de este hidalgo entre las agrestes montañas de las Alpujarras: Cervantes, Gracián, Quevedo, Saavedra Fajardo, Zurita, Argote de Molina, Estrada, Herrera, Solís, Escolano, Ovidio, etc., se mezclan con libros de devoción o vidas de Santos, con la Aritmética o con atlas. En ellos aprenderían sus primeras letras y el acercamiento a la verdadera cultura de la época sus numerosos hijos. En ellos descubririan otros mundos e intentos de perfección de éste gracias a la religión y a la teoría política. En estos libros cuajarian las vocaciones de Esteban o Manuel Antonio y sobre todo la del jesuita Pedro Murillo-Velarde y Bravo abierta a tantos saberes, aunque todos ellos supeditados a su religión jesuítica y al derecho.

Don Jacinto y su familia que residiría tanto en Laujar, como en Granada - aunque en este caso esporádicamente- al igual que en el Presidio, tanto por motivos de su carrera política como por sus negocios o por los estudios de sus hijos, es ante todo un militar y su familia la de un militar, entiéndase, la de un militar provinciano y con las características de la época, no un militar enteramente profesional. Esta condición y su nobleza, junto su fidelidad al Rey don Felipe $V$ y a su dinastía de Borbón, le llevaron a participar en la guerra de Sucesión como se ha atestiguado ya gracias a su testamento fechado en 1706. No obstante no moriria en la guerra, sino que seguiria su vida hasta el día 5 de septiembre de 1722 en que la entregó a su Dios: 


\section{LIBRERÍA DE JACINTO MURILLO VELARDE Y SU TASACIÓN $-1722-$}

Un librete pequeño del Arte de la Nueva Guerra.

Un libro pequeño de Teatro del Mundo.

Un libro Atlas abreviado.

Un libro de horas del Oficio de N. ${ }^{\text {a Señora. }}$

Dos tomos de Flors Sanctorum.

Un libro de Obras de Gracián.

Un tomo de Sólo Madrid es Corte.

Seis tomos de David.

Dos tomos de la Historia de Mariana.

Tres tomos de la Vida de Santa Teresa.

Un tomo de Santa Teresa de Biterbo

Dos tomos de Obras de Quevedo. Un tomo de Refranes a la Salud.

Nobleza de España.

Espexo del Soldado.

Aritmética.

Antigüedades de Vélez.

Empresas Políticas.

Guerras Civiles de Francia.

Dos tomos de las Gacetas de cuatro años.

Un tomo de San Pedro de Alcántara.

El Parnaso, las Tres Musas y Políticas de Quevedo.

Agricultura del Prior.

Nobleza de Andalucia.

Indices y Anales de Aragón.

Anales de Argensola.

Doce tomos de la Corte Santa de Causino.

Historia de Troya.

Mística Ciudad de Dios.

Don Pedro Cubero Sebastián.

Crónica de San Francisco de

Paula.

Población General de España.

Agricultura de Herrera.

Historia de México de Solís.
Institución del Colegio Mayor

5 reales de Cuenca. 2 reales

Dos tomos de Máximas del

12 reales padre Garau.

40 reales Celos divinos.

Escuela de Daniel.

10 reales Cuatro Tomos del Año Virgí-

30 reales neo.

8 reales Vida de San Isidro.

Obras de Murillo.

8 reales Fustes de Murcia.

42 reales San Antonio, Noticias de España.

6 reales

5 reales

5 reales

24 reales

6 reales

5 reales

4 reales

24 reales

Cortes de Valencia.

4 reales

Monasterio de Osera.

24 reales

Catecismo.

4 reales

5 reales

5 reales

Cinco tomos de Flor Histórico. 20 reales

8 reales Fiestas de Salamanca. 2 reales

34 reales El clérigo agradecido. 5 reales

6 reales Filosofía de Tesauro. 5 reales

4 reales Mártires de la Alpujarra, de Es-

6 reales colano. 4 reales

6 reales Monarquía Perfecta. 5 reales

4 reales Juego de Damas. 3 reales

8 reales El Entretenido. 3 reales

16 reales Cuaresma de Estrada. 5 reales

Cuatro tomos de papeles diver-

4 reales sos. 12 reales

Ovidio. 3 reales

8 reales Un libro de latín. 2 reales

Tratado de Solfa. 6 reales

6 reales Un libro de Cortes. 3 reales

8 reales Gobierno del pobre. 10 reales

15 reales Dos tomos del Quixote. 12 reales

100 reales

16 reales

100 reales

5 reales

60 reales

6 reales

12 reales

11 reales

10 reales

6 reales 
«Don Juan Pedro Peláez, cura y padre general de menores de este partido por Su Magestad. Digo que en la villa de Lauxar murió el capitán don Jazinto Murillo Velarde, el qual a dexado hixos y herederos menores y así mismo diferentes vienes así muebles como raízes y semovientes de los quales combiene al derecho y utilidad de los dichos herederos menores se haga quenta, división y partizión entre ellos y los demás ynteresados $y$ herederos mayores. $Y$ para que tenga efecto, a vuestra merzed suplico, sea servido de mandar se haga dicha partizión y para ello se notifique a los dichos interesados y herederos mayores y nombren por sus partes contadores tasadores y partidores que se junten con los que io nombre por los dichos menores y que por los omisos y ausentes la justizia de dicha villa nombre de ofizio. $Y$ a los que se nombraren se le notifique, lo azeten y juren..» ${ }^{25}$.

Jacinto Murillo Velarde y Ocaña a su muerte poseía un capital bruto valorado en 89.680 reales repartidos en fincas, casas, alhajas, muebles, etc., e incluso algún que otro cargo como el de alcalde provincial de la Santa Hermandad con voz y voto de regidor en la villa del Presidio y que estaba valorado en 3.000 reales. Lo que ocurre es que interesados en su capital no sólo se encontraban sus hijos y herederos sino que también existía un nutrido grupo de acreedores a deudas que montaban 9.791 reales. Si a ello se le resta los bienes propiedad, por diferentes conceptos, de su esposa Magdalena Bravo, la herencia a repartir no era tan jugosa como la primera cifra dada podía hacer pensar.

Siete eran los hijos llamados a suceder al capitán don Jacinto. Excluido quedaba Pedro Murillo Velarde y Bravo, que por su condición de jesuita hubiera debido entregar a la Compañía sus bienes, en caso de suceder. Su apartamiento de dicha herencia es total, tan extremo que ni siquiera se le nombra en los autos comentados, aunque si en el testamento de su padre de $1706^{26}$. Así, pues, los hijos que heredaron

\footnotetext{
25 A.H.P. A., Justicia, J.70, sin foliar.

26 Ibidem, Protocolos, p. 1482, fol.11-15. En el testamento referido que se inicia de la siguiente forma: "Yn Dei nomine, amen. Sepan quantos esta carta de testamento última y fin voluntad vieren como yo don Jacinto Murillo Velarde, vecino natural y capitán de esta villa de Lauxar y rexidor perpetuo de la del Presidio de estas Alpuxarras, ... Digo que por quanto Su Majestad que Dios guarde a sido serbido de mandar que la nobleza de esta Andaluzía salga a defender esta Monarquía. Y por cuanto como tal caballero hixodalgo notorio estoy alistado en la villa de Uxixar desde el dia doce de este presente mes ante el alcalde mayor, con el ánimo de servir en la campaña, como tal defender los derechos del señor don Felipe Quinto nuestro Rey y los de la ley católica que por tantas partes es inbadida. Estando como estoy sano de mi cuerpo en mi buen juicio y entendimiento, tal qual Dios nuestro Señor a sido serbido de darme y temiéndome de muerte que es natural de que ninguna criatura se puede es-
} 
fueron: el capitán don Andrés Murillo Velarde y Bravo (6.971 r.); doña Maria Murillo (14.245 r.); don Esteban Murillo (6.932 r.); doña Magdalena Murillo (13.122 r.); don Juan Manuel (10.482 r.) ${ }^{27}$; don Manuel Antonio Murillo (6.906 r.); y por último don Jacinto Murillo Velarde y Bravo $(7.405 \text { r. })^{28}$.

Como se puede apreciar los hijos varones salen - menos Juan Manuel- más perjudicados, pero es que ya habían recibido buena parte de su herencia en adelantos en concepto de ayudas para iniciar sus vidas, de ahí el desfase entre hombres y mujeres. Es más, otros como el primogénito don Andrés Murillo Velarde y Bravo, regidor perpetuo y capitán, no sólo heredaría los bienes de su padre sino que sería, además, el titular del vínculo y mayorazgo fundado por su tío el obispo don Andrés.

El heredero de los Murillo, don Andrés Murillo-Velarde y Bravo, había nacido en Granada en la colación de San Miguel el 1 de marzo de 1700, fue capitán de una de las antiguas compañías de milicias de Laujar. Pasó la mayoría de su vida en la villa de sus antepasados y con él se puede decir que comienza la decadencia de su linaje pues ninguno de sus descendientes gozaría de la importancia de algunos de los individuos de generaciones anteriores. $Y$ con él se perdería la varonía de los Murillo Velarde, pasando el mayorazgo de que era titular a manos femeninas, pues aunque tuvo tres hijos de su matrimonio con doña Isabel Josefa Murillo Velarde - contraído el 27 de octubre de 1724, la que era hija de don José Sánchez de Garcí González MurilloVelarde y de doña María Pérez de Arcos-: Melchora Josefa, Pascual y Francisco Javier ${ }^{29}$, y si bien es cierto que en mayo de 1740 su hijo Pascual ostentaba el vínculo, a la muerte de los dos varones sin hijos éste pasaría a manos de doña Melchora Josefa que en septiembre de

cusar y para la claridad de mis dependientes y pas de mis herederos quiero hazer mi testamento, él y buena dirección y discargo de mi conciencia...". Digo que en este testamento, asi iniciado, el otorgante declara que en esas fechas son sus herederos: "Esteban, Josepha. María, Pedro, Andrés, Juan, Jacinto y Madalena, mis ocho ixos y de doña Madalena Vravo y Valdibia, mi muxer", por cierto el primer entrecomillado ya ha sido publicado en otras aproximaciones a Murillo.

${ }_{27}$ Juan Manuel, nacido en Laujar, fue realmente militar profesional, en 1729, iniciaba su carrera siendo cadete del regimiento de infantería de Cantabria, Ibidem, p. 1446, fol.64$64 \mathrm{v} .{ }^{\circ}$.

29 A.N.G., Protocolos, Ugíjar 1703, escribano Narciso Beltrán, fol. 45-52. 
1750 casó con don Juan Francisco de Córdoba y Peralta, vecino de Ugíjar, abogado de la Real Chancillería de Granada y teniente de alcalde mayor de las Alpujarras ${ }^{30}$.

El sueño de los Murillo Velarde de superación social declinaba en sus descendientes y quedaba circunscrito a la categoría de hidalgos acomodados de provincias. No obstante durante un tiempo esto no fue asi, fue algo más, y todo gracias a la unión existente entre dos hermanos: Andrés y Jacinto Murillo-Velarde y Ocaña. Así lo había dispuesto el licenciado don Pedro Murillo Velarde y López de Mayor y así lo habían llevado a efecto sus hijos acabados de nombrar. $Y$ es que como ha sido referido, entre Andrés y Jacinto existía un verdadero deseo de superación y encumbramiento del linaje y una conjunción de intereses. Sobre todo Andrés se encargaría de elevar a la familia y Jacinto, además de ser su fiel aliado, aportaría la continuidad del linaje familiar, ese era ni más ni menos su ideal. Ideal que se cumpliría en la carrera que a continuación se expondrá de Andrés Murillo Velarde y Fernández de Ocaña, en su deseo de aumentar su capital y de apartarlo del control eclesiástico para ponerlo a disposición de su hermano y sobre todo de la mayor honra familiar.

Esto básicamente se aprecia no sólo en la continua ayuda que ofrece el futuro prelado a los hijos de su hermano Jacinto en sus carreras, concretamente a Esteban, Manuel Antonio y Pedro, sino también a aquellos que no seguían la vida eclesiástica sino inclusive la militar, como es en el caso del mencionado cadete Juan Manuel Murillo Velarde y Bravo que en escritura de 5 de febrero de 1729 otorgada en Laujar afirma - tras la muerte de su tío el obispo de Pamplona- que éste le había nombrado canciller del obispado y que «por aber estado ausente de dicha ciudad de Pamplona en diferentes ocasiones, despachaba y servía dicho empleo otra persona" y que ahora intentaba cobrar lo que ésta última le debía ${ }^{31}$. Como se ha dicho no sólo en este auxilio directo se aprecian las intenciones del prelado, sino que éstas se manifiestan con mayor relevancia en la fundación de capellanías y mayorazgos.

A.H.P. A., Protocolos, p. 1447, fol.108-108v. ${ }^{\circ}$

31 Ibidem, Protocolos, p. 1446, fol.64-64v. . Sobre el obispo Andrés Murilio Velarde, basándose en la oración fúnebre que se hizo a su muerte y en documentación navarra, existe un interesante trabajo - sobre todo en lo que a su actividad de obispo de Pamplona en $\mathrm{Na}$ varra se refiere- en J. Goñı Gaztambide, Historia de los obispos de Pamplona, VII, siglo xim. Ediciones Universidad de Navarra, Pamplona, 1989, pp. 196-251. 
Ocurría en Laujar - llevado a cabo por don Jacinto en virtud de poder de don Andrés efectuado en Toledo el 4 de noviembre de 1709 ante Manuel Ruiz Machuca- en presencia del escribano Ignacio Beltrán, concretamente la creación de la capellanía el 3 de diciembre de 1709 y el vínculo y mayorazgo el 9 de diciembre de 1709 . Todo tenía como objeto crear una masa patrimonial destinada a preservar el estatus alcanzado por los Murillo. En correlación se construía una casa principal lujosamente decorada o la capilla de la familia que estaba más que decentemente adornada con un escudo familiar, cuadros, entre ellos uno que en su motivo estaba retratado como oferente el obispo, etc.

$Y$ es que pese a que la figura paterna siempre es importante y más en estas épocas, sin duda hay otra que sobresalió y fue apoyatura principal en la vida de los Murillo Velarde, hijos de Jacinto y Magdalena, ésta no es otra que la del ya referido Andrés José Murillo Velarde y Fernández de Ocaña, hermano de don Jacinto y por lo tanto tío de Pedro y sus hermanos.

Don Andrés Murillo Velarde y Fernández de Ocaña fue bautizado en Laujar el 13 de diciembre de 1679. Es destinado a la carrera universitaria por sus padres, mientras que su hermano mayor Jacinto se queda como representante del linaje en su solar, la villa de Laujar. Por ello se traslada Andrés Murillo a Granada donde consigue una beca en el Colegio de San Miguel. En éste y en la Universidad de Granada comenzará sus estudios y carrera, obteniendo el grado de bachiller en Artes el 17 de febrero de $1690^{32}$. En Granada conseguirá el 10 de junio de 1691 el grado de licenciado en Artes, como reza la siguiente inscripción:

«En Granada, en diez de junio de noventa y uno, siendo las çinco de la tarde, y estando en el general maior de esta Ymperial Universidad. Don Andrés Murillo, natural de esta çiudad, y colegial en San Miguel, y don Manuel Guaço Calderón, natural de Aguilar de Campo, diócesis de Burgos, reçibieron el grado de Liçençiadc y maestro en Artes, de mano del señor doctor don Martín Torrico de Pedrajas, abad de la Yglesia Colegial del Salvador y Provisor de este Arçobispado, señor Chançiller de esta Universidad. Aviendo preçedido la prueba y el examen que manda la constituçión, en que fueron aprobados por todos los votos. $Y$ aviendo asímismo preçedido el paseo público y la profesión de fe y el juramento de la Pura Conçepçión de nuestra Señora" ${ }^{33}$.

32 A.U.G. Leg. 1411.

33 Ibidem, Leg. 1711-2, fol. 2. 
Del Colegio de San Miguel y de la Universidad granadina pasará a la prestigiosa Universidad de Salamanca, obteniendo otra beca en el Colegio Mayor de Cuenca, en la citada Universidad.

En la Universidad salmantina alcanza Andrés Murillo Velarde el grado de doctor en Teología e inicia verdaderamente su carrera eclesiástica que le llevará a Badajoz como lectoral, a Murcia como magistral de su Catedral - siendo tanto en Murcia como en Badajoz examinador sinodal de ambos obispados- y por último ocupará una canongía en el cabildo de la iglesia primada de las Españas, la catedral de Toledo. Su carrera, como la mayoria, no está exenta de los favores y contactos basados en antiguas amistades, pues no es casual que don Francisco Balero y Losa, fuese bachiller por Granada y ganara en ella una oposición a la Cátedra de Prima de Leyes de la Universidad el 25 de abril de $1690{ }^{34}$. Alli debieron entablar amistad Andrés Murillo Velarde y este bachiller que con el tiempo llegaría a ser Obispo de Badajoz y Arzobispo de Toledo, Primado de las Españas, Canciller Mayor de Castilla y del Consejo de Su Majestad. El antiguo amigo de los años de Universidad, convertido de bachiller en prelado, arrastrará y potenciará desde su importante evolución en el seno de la Iglesia española la carrera de Andrés Murillo Velarde y Fernández de Ocaña.

Gracias a las influencias de Valero y Losa alcanzará entre otras la canongía de Toledo, y a la muerte del amigo y arzobispo será él el encargado -en representación del cabildo de Toledo- de realizar el 23 de mayo de 1720 la oración fúnebre, que tituló «El Sumo Sacerdote y Santo Onías, copiado en el llustrísimo y Reverendísimo Señor D. Francisco Valero y Losa» ${ }^{35}$.

Pero con la desaparición del amigo y protector no terminaría la buena suerte y carrera eclesiástica de Andrés Murillo Velarde, ésta llegaría a su máximo expiendor cuando Luis I de España le nombró obispo de Pamplona en 1724. El 9 de mayo de ese referido año lo notificaba al Cabildo de Pamplona. Pero hasta casi un año después no pudo anunciar su ida a su nueva sede pues las bulas tardaron en llegar a la Corte, una vez que el Papa había admitido dicha disposición

34 Ibidem, Leg. 1411 , fol. 343.

35 A. Murillo Velarde, El Sumo Sacerdote y Samto Onías, copiado en el llustrisimo y Reverendísimo Señor D. Francisco Valero y Losa. Imprenta de Pedro Marques, Toledo, 1720. 
del monarca español el 21 de marzo de 1725. En Toledo Andrés Murillo Velarde sería consagrado obispo por el Cardenal Arzobispo de Toledo y amigo Don Diego de Astorga y Céspedes, el 1 de mayo de 1725.

No sería hasta el 19 de junio de 1725 cuando el nuevo obispo de Pamplona Andrés Murillo, llegara a su sede. En su cargo sólo estuvo tres años, siete meses y veinte días, pues la muerte en 1728 cerró una carrera que podría haber sido más fecunda.

Fue Andrés Murillo Velarde más un predicador que un intelectual, su verbo resulta elogiado en la oración fúnebre a Valero y Losa, concretamente en la censura del Dr. D. Francisco Antonio de Cisneros y Mendoza a dicho discurso se comenta sobre la elocuencia de Murillo que utan grande orador, lo que por tan discreta, sabia y elegante oración en la común aclamación de todos se le debe... y siendo superior a qualquier elogio su grandeza es preciso que por más que quiera mi afecto ponderar lo crecido de sus aciertos" ${ }^{36}$. Durante el pontificado en Pamplona Murillo Velarde desarrolló e impulsó bastantes misiones para un mejor perfeccionamiento en la fe de sus fieles y fue celoso custodio de determinados principios como el de la persecución de comedias, cosa que le enfrentó al cabildo municipal y al eclesiástico. Enfrentamiento con éste último que no sería el único, pues sus ideas y formas de llevar su diócesis chocaron pronto con los canónigos pamplonicas, y más aún chocó la labor de su vicario don Gaspar de Miranda y Argaiz, arcediano de Vizcaya. Esto dio lugar a procesos, pleitos y disputas entre el cabildo eclesiástico y su obispo y su vicario. Todo terminaría con un postrero viaje a Andalucía, concretamente a Arcos de la Frontera donde habia viajado para recuperar su deteriorada salud, - habiendo testado previamente en Toledo, hacía años, el 12 de marzo de 1721 ante Juan de Piedrahita ${ }^{37}$ - sin embargo el 3 de noviembre de 1728 :

"A las dos de las mañana le despertó un vivísimo dolor, que sintió en un hombro... de allí a media hora le repetió con mayor viveza, y estando rodeado de toda su familia, moviéndose aquel dolor desde el hombro hacia el pecho, dixo su llustrísima: Jesús, yo me muero, ya me llega al corazón, adios hijos... Y reclinado la cabeza sobre la almoada, como

Ibidem, censura.

A.H.P. A., Protocolos, p. 1447, fol.103-118v.. 
quien se echa a descansar, sin movimiento alguno y con una suavidad imponderable... descansó en el Señor " ${ }^{38}$.

De este modo terminaba la vida de quien había elevado a los Murillo Velarde granadinos de la categoría de hidalgos provincianos a la de caballeros con muchas posibilidades de futuro, pues el contar con un prelado entre sus filas no era algo precisamente sin importancia en esas épocas.

No obstante la prematura muerte del prelado Andrés Murillo Velarde podía y pudo retrasar las carreras de sus sobrinos y las metas a las que podrían haber llegado con su ayuda. Ayuda que sin embargo prestó tanto a Pedro, objeto de estudio de este trabajo, como a sus hermanos Manuel y Esteban, primero en vida y después de su muerte con las relaciones de personas influyentes a las que había elevado a su familia.

Ante la defunción del obispo, independientemente de los bienes privativos que ya habían pasado a los Murillo, deja heredero universal de los bienes que quedaren de su expolio a un amigo suyo de la época toledana, el doctor don Fernando Merino Franco, dignidad de la Santa Iglesia Primada de Toledo, aquí surge la ruptura de la unidad familiar que hasta entonces había reinado entre el prelado y su hermano el capitán y que ellos mismos habían propugnado. Armonía que pasa a enfrentamiento y pleitos entre herederos, albaceas, apoderados, etc. La causa se encuentra en varias actuaciones llevadas a cabo por el presbítero licenciado don Melchor de Ocaña y Murillo Velarde, comisario del Santo Oficio y apoderado del obispo y, después, de su heredero el doctor Merino Franco. El primero, en virtud de los 2.200 reales que se le debían al fallecido obispo por parte de su hermano el también desaparecido don Jacinto, decide agregar a la capellanía y al vínculo un trozo de casa para redondear la fachada de la casa solariega y otros bienes como ocho lienzos de pintura fina para adorno de la sala principal de la casa, ocho sillas de moscovia, un sello de plata con el escudo de los Murillos, dos espejos grandes de cristal con sus marcos negros, una lámina del retrato de Felipe $V$ y gran parte de la librería de don Jacinto.

38 P. de ALESON, Oración funebre en las exequias que en la Santa lglesia Chatedral de Pamplona consagraron a la buena y piadosa memoria del llustrísimo señor D. Andrés de Murillo y Velarde, su meritisimo obispo. Pamplona, s.a., tol. $4 \mathrm{v}$. . 
La reacción no se haría esperar, el capitán don Andrés Murillo Velarde y después su viuda en nombre del nuevo titular don Pascual Murillo Velarde y Murillo Velarde, entablaron pleito contra Ocaña como apoderado y contra Franco Merino como heredero. Se pleiteó, se intentaron arbitrajes que no se cumplieron, todo seguía agriando las relaciones familiares, para evitar que todo ello continuara se sometieron por segunda vez a arbitraje, en esta ocasión al del doctor Esteban Rodríguez de Cos, comisario del Santo Oficio, abad de la Real Iglesia Colegial de Granada del Salvador, visitador general del arzobispado, capellán de honor de Su Majestad el Rey, juez sinodal del arzobispado y conservador de las religiones de Mínimos y Padres de San Gregorio. El laudo arbitral dado por esta dignidad eclesiástica, dictado el 14 de mayo de 1740 en la villa alpujarreña de Ugíjar, esta vez fue acatado, pero ya nada quedaba de esas intenciones unidas sin excepción entre diversos familiares para llevar a lo más alto posible de la escala social al linaje Murillo, frente a lo común surgía lo individual.

Pese a todo, el obispo Andrés Murillo Velarde y Fernández de Ocaña fue el hacedor de ciertas facilidades de las que gozaron los Murillo Velarde hijos de don Jacinto y de doña Magdalena Bravo y Valdivia. Y entre todos ellos sobresalen, sin duda, junto al autor del Cursus luris Canonici, Esteban y Manuel Murillo Velarde y Bravo, ya convertidos en individualidades no en eslabones de un ideal familiar superior, como ocurría cuando empezaban sus estudios estando vivos su padre y su tío ${ }^{39}$.

D. Esteban, D. Manuel y don Pedro Murillo Velarde y Bravo. Tres que se sepa son los hijos que cursaron estudios en las Universidades españolas y principalmente Granada, aunque no se deben olvidar Salamanca y Alcalá de Henares.

Por edades el primero de ellos es Esteban Murillo Velarde y Bravo, nacido en Laujar y bautizado en su Parroquia el 20 de enero de $1691^{40}$.

39 A.H.P. A., Protocolos, p. 1449, fol.78-86.

40 En Laujar, "En veinte dias del mes de henero de mil seisçientos noventa y un año, baptiçé a Estevan Joseph que naçió el día 26 de diziembre de mil seisçientos noventa y un años. Hijo de don Jaçinto Murillo y doña María Magdaiena Bravo Valdivia, su muger. Fueron compadres don Françisco Arevalo, veçino del lugar de Cádiar, y Doña Leonor de Ocaña, donçella, veçina de esta villa. Fueron testigos Benefiçiado Gómez de Valdivia, Alexandro de Ocaña y Fernando Arias, veçinos de esta villa. $Y$ lo firme. Liçençiado Don Antonio Cebrian (Firmado y rubricado)", A.U.G. Registro de pruebas del Colegio de Santa Cruz, libro 10, fol. 197v. ${ }^{\circ}$ 
Trasladado a Granada, consigue beca en el Colegio de San Miguel, donde ya había sido colegial su tío y mentor el obispo Andrés, entonces canónigo. Allí se dedica al estudio del Derecho Canónico y el 15 de julio de 1712 ,

"Como a tas çinco de la tarde y estando en el General mayor de esta Unyversidad Don Estevan Joseph Murillo Velarde, natural de Lauxar, de este arçobispado, y colegial del Señor San Miguel, de esta ciudad, reçivió en esta Universidad el grado de Bachiller en la Facultad de Sagrados Cánones de mano del señor Doctor don Nicolás Rosalío de Navarrete, que hizo ofiçio de Decano. Aviendo preçedido la prueba de sus cursos, el acto y examen que manda la constituzión, después de aver hecho el juramento de la defensa de la Purísima Concepción de nuestra Señora" ${ }^{4 !}$.

Su carrera universitaria continúa y estando vacantes por enfermedad y otros accidentes de los propietarios las cátedras de Instituta, Decreto, prima de Cánones y prima de Leyes en 1700 , concretamente el 20 de octubre, a propuesta del Rector de la Universidad de Granada en un claustro de Comisarios de la Universidad se le vota y elige como sustituto de la Cátedra de Instituta de la que era propietario el Dr. Rosillo ${ }^{42}$. El 17 de octubre de 1713 volvería Esteban a hacerse con esa cátedra, también como sustituto. Ese mismo año, el 11 de noviembre, es electo consiliario de la Universidad por el Colegio de San Miguel, junto al doctor Zaragoza.

Al año siguiente el 5 de diciembre de 1714 saliendo a concurso la cátedra de Código se acordó por el claustro se le otorgase a Esteban Murillo y,

«mandó el señor Rector entrase a tomar de sus serviçios como es costumbre... y se le dio la dicha cathedra al dicho don Estevan, nombrados dos caballeros comisarios para que le diesen la posesión de ella, que fueron el señor Raya y el señor Torre" ${ }^{43}$.

41 A.U.G., Leg. 1711-2, fol. 207.

42 «En Granada en veinte días del mes de otubre de mil seteçientos años, siendo como a las diez del día se juntaron a claustro los señores commisarios de esta Universidad, con llamamiento antediem del señor Rector, de que dieron fe los vedeles, y aviendo sabido dicho llamamiento y hecha señal con la campanilla, el dicho señor rector propuso que algunos de los señores catedráticos propietarios por su ausençia y otros por enfermedad, no asisten las Chátedras de Leyes y Sagrados Cánones como conviene. $Y$ así que era preçiso nonbrar los sustitutos por el tiempo que estubiesen o ausentes o legítimamente impedidos. $Y$ pasando a votar sobre este punto, de común acuerdo, votaron de la forma siguiente: Bachiller don Es. teban Murillo para la cátedra de Instituta", A.U.G., Leg. 1420, fol. 223v. ${ }^{\circ}$.

43 Ibidem, fol. 248. 
Anteriormente el 24 de diciembre de 1712, el bachiller Esteban Murillo Velarde había conseguido su beca en el Colegio Mayor de Santa Cruz de Granada, abandonando su antiguo Colegio de San Miguel ${ }^{44}$. Siendo ya colegial de Santa Cruz, catedrático de la Universidad y ya licenciado, obtuvo por Granada el grado de doctor:

"En Granada en veinte y nueve dias del mes de abril de mil seteçientos y diez y siete años, siendo como a las diez del día, se juntaron en claustro los señores doctores de esta Universidad con llamamiento anterior del señor Rector, de que dieron fe los vedeles, y aviéndose hecho señal con la campanilia, y leidose el dicho llamamiento, entró en el salón del claustro el lizenziado don Estevan Murillo y aviendo captado la venia, se sentó y pidió por merçed al claustro, que fuese servido de averlo por presentado para el grado de doctor en la facultad de Sagrados Cánones, en atezión a averlo honrado la Universidad con el grado de liçençia en la dicha facultad... Y aviendo oído y entendido las pretençiones... pasaron a votar, cada uno en su lugar, sobre la admisión de los pretendientes. De común acuerdo se resolvió que se admitieren teniendo probados los cursos y hechas las lecciones que manda la constituçión y que desde luego pudiesen repartir los papeles para los actos, poniendo el edicto que se acostumbra, que si algunos pereçiesen más antiguos pudiesen actuar y depositar en tiempo, que no les pase perjuicio a su antiguedad" ${ }^{45}$.

Pero ante una serie de problemas surgidos en la tramitación de su doctorado Esteban Murillo Velarde debió, a instancias del Rector, de presentar de nuevo solicitud para ser doctor el 14 de septiembre de 1717 , año en que pese a todo consiguió doctorarse. Además de sus grados académicos y de la cátedra que desempeñó en Granada fue igualmente rector de su Universidad. Por ejemplo:

"En Granada, onze de diziembre de seteçientos y veintidós años. Juntos muchos señores Doctores y Maestros de esta Unyversidad, en el General Maior para la elección de señor Rector y consiliarios. Dicha la misa de Spíritu Sancto, subieron al Salón de Claustros, el señor Rector, señor Chançiller, señores Valdés, Raya, García, Maestro Unamuno y señor Revilla y aviéndose leído la primera y segunda constituçión, hizieron todos en manos del señor Rector el juramento en la forma ordinaria y se pasó

44 "Ego Bachiller Stephanus Josephus Murillo et Velarde, natus in villa de Laujar, receptus fui in collegam huius maioris regalis que Sancte Crucis fidei collegis. Anno a nativitate domini milleximo septingentesimo duodecimo, die vigessima quarta mensis, decembris. In cuius fidem hoc propia manu scripsi et subscripsin, A.U.G., Libro del Colegio Mayor de Santa Catalina y Santa Cruz (Libro Azul), fol. 170.

45 Ibidem, Leg. 1420, fol. 13v. . 
a elegir al señor Rector, votando cada uno con tres zédulas. Que puestas en el archita destinada para ese efecto y avierta por el señor Chançiller, halló el dicho señor veintiquatro, según el número que votaron... y quedó electo dicho señor Murillo, por señor Rector» ${ }^{46}$.

El 16 de noviembre de 1722 recibió obediencia de los doctores granadinos. Su equipo de gobierno estuvo formado además de por él -Esteban Murillo Velarde- como rector, de cinco consiliarios: uno teólogo, otro jurista, otro médico y por último otros dos por el Real Colegio. Entre estos estaba el licenciado José de Mérida Morales, alpujarreño como los Velarde, y unido a ellos por lazos familiares. Licenciado que también llegaría a Rector en 1733.

Don Esteban Murillo Velarde sería relevado como Rector en 1723 por el doctor don Luis de Marina. Murillo Velarde además -en lo que se refiere a su carrera eclesiástica - fue canónigo doctoral de Guadix y en 1721 hizo oposición a la doctoral de Salamanca y en 1722 a la de penitenciaría de Toledo, en ambas ocasiones sin mucho éxito, pese a las afirmaciones en su favor como la contenida en una carta remitida por el presidente y cabildo canónico de la Iglesia de Salamanca dirigida al Rector del Colegio de Santa Cruz el 29 de junio de 1720:

"Con suma estimación reçebimos la de Vuestra Señoria, en que nos significa las recomendables prebendas del señor doctor don Esteban Joseph Murillo Velarde, su colegial, opositor al canonicato doctoral vacante de esta Santa Yglesia. $Y$ siendo tan notorias, que quedarán canonizados con sus actos, nos aseguran ser meritorio de éste y de otros mayores empleos. $Y$ nosotros nos interesaremos mucho en tenerle por nuestro hermano" 4 .

El 21 de febrero de 1724 caía enfermo y se procedió a sustitución en su cátedra, la que alcanzaría su lejano pariente Mérida y Morales. Esta enfermedad es muy posible que le llevara a la muerte pues ha sido imposible conseguir más datos de Esteban José Murillo Velarde.

En siguiente lugar - aunque sea el tercero por fecha de nacimiento- fue también universitario Manuel Antonio Murillo Velarde y Bravo. Mientras que Esteban, hasta ahora, había pasado desapercibido por el contrario de Manuel Antonio había ya noticias aunque muy vagas. Por

46 Ibidem, fol. $111 \mathrm{v} .^{\circ}-112 v^{\circ}$

47 Ibidem, Colegio de Santa Cruz, Libro 27, pieza 29. 
lo que merece la pena profundizar en su biografía. Nace, Manuel Antonio, al igual que sus hermanos, en la villa de Laujar el 8 de marzo de 1709, y fue bautizado en su Iglesia por el párroco Cecilio Ruiz de Deo el 17 de marzo de ese mismo año ${ }^{48}$.

Transcurrida su niñez y a imitación de su tío y hermanos se traslada a Granada en 1724 donde consigue beca de colegial jurista en propiedad de San Miguel. En Granada estudia Sagrados Cánones, solicitando en el año 1729 se le confiriera el grado de bachiller, pues demostró haber cursado los estudios suficientes que había comenzado en 1725 y concluido el 4 de abril de $1729{ }^{49}$.

Igualmente siguiendo a Esteban José, pasa del Colegio de San Miguel al Colegio de Santa Cruz el 18 de enero de $1730^{50}$. En él sería rector en diversas ocasiones, la primera vez en 1733, como él mismo refiere en el libro registro de rectores del Colegio de Santa Cruz:

"Ego D. Emmanuel Antonius Murillo et Velarde, electus fui in Rectorem huius al me Domus Maioris, atque Regalis Collegi. Die quinta, mensis iaunuaris, anno Domini mileximo septingentesimo trigesimo tertio» ${ }^{51}$.

Rectorado de Santa Cruz que repetiría en 1733, 1734 y 35 . Ese mismo año el Rector de la Universidad de Granada, que lo era su ya mencionado pariente José de Mérida Morales, afirmó que tenía:

48 "En diez y siete de marzo de mil setezientos y nuebe, yo el liçençiado Çeçilio Ruiz de Deo, cura de la Parroquial de esta villa de Laujar, baptizé solemnemente a Manuel Antonio Joseph, que naçió el día 8 de este mes. Hijo del capitán don Jaçinto Murillo Velarde, regidor perpetuo del Presidio y Comisario General del Partido de las Alpujarras, y de doña Magdalena Bravo y Valdivia, su legítima mujer. Abuelos paternos don Pedro Murillo Velarde, Auditor General de la Costa de este Reyno, y doña María de Contreras, naturales de esta villa. Abuelos maternos don Matías Bravo, regidor perpetuo del Presidio, y doña Maria de Valdivia, natural del Presidio. Fueron sus compadres el doctor don Manuel de Mogollón Calderón y Altamirano, cura de esta Sancta Yglesia y Comisario del Santo Ofiçio de la Inquisiçión y doña María de Ocaña Bailón. Testigos el liçençiado don Manuel Méndez de Castro, vezino y vicario de esta villa, don Luis Ortiz de los Ríos, beneficiado, y don Juan González Zambrana, presbítero. Y lo firme, Lizenziado Zezilio Ruiz de Deo", Ibidem, Libro 11, fol. 253.

49 A.U.G., Leg. 1601-045, fol. 1.

50 "Ego D. Emmanuel Antonius Murillo Velarde, natus in villa qui vulgo nominant Lauxar, receptus fui in collegam huius maioris as Regales Colegii. Anno a nativitate domini millesimo septuagentesimo trigesimo, die decimo octabo, ianuarii. In cuius fides hoc propia manu scripti et subscripti", Ibidem, Libro del Colegio Mayor de Santa Catalina y Santa Cruz (Libro Azul), fol. 184.

51 lbidem, fol. 49. 
«notiçia de que el bachiller don Manuel Murillo, Colegial del Real y Mayor de Santa Cruz de la Fe, quería presentarse al grado de liçençia en Sagrados Cánones y que si el claustro gustava, entrara a pedir su presentaçión’ 52 .

De este modo en febrero de 1734 el pretendiente a licenciado - solicitado el grado referido- realizó demostración de su limpieza de sangre pues:

"para rezivir dicho grado según estatutos de esta Imperial Universidad deve prezeder informaçión de legitimidad, limpieza de sangre y buena vida y costumbres. Y para cumplimiento de lo referido presento mi genealogía» ${ }^{53}$.

Las probanzas comenzaron el 10 de febrero de 1734 y fue aprobado su expediente el 15 de febrero de 1734. Ese año fue año de dichas académicas para Manuel Murillo Velarde, ya que el 28 de mayo de 1734, estando vacante la Cátedra de Instituta y siendo cuarenta y nueve los votos efectuados para elegir pretendiente las cuarenta y nueve cédulas señalaron a Manuel Murillo. Por lo tanto el mismo 28 de mayo, sobre las once de la mañana:

"los señores doctor don Diego de la Torre y don José Ventura de Córdova, llevaron a la Cáthedra del General de esta Ymperial Universidad a dicho señor liçençiado don Manuel Murillo Velarde, y aviendo subido a ella explicó un párrafo del libro Instituta, in voce, y aviendo baxado de dicha Cáthedra le dieron la enhorabuena. $Y$ en todo lo referido no hubo contradicción» 54 .

Pero aquí no acaban los éxitos de 1734 para Velarde, pues siendo ya licenciado es nombrado Rector de la Imperial Universidad. Cargo que volvería a ostentar el 4 de diciembre de 1738. Anteriormente durante el curso 1737-38 había desempeñado el cargo de consiliario de la Universidad por el Real Colegio de Santa Cruz y Vicerrector de la Universidad de Granada, al igual que en 1732. Su carrera Universitaria en Granada termina cuando fue substituido en su Cátedra de Instituta el 22 de noviembre de 1740, por haber sido nombrado canónigo doctoral de Baza del Reino de Granada. Y es que la salida lógica de todo

52 A.U.G., Leg. 1420, fol. 251.

53 Ibidem, Leg. 1473-153, fol. 1.

54 bidem, Leg. 1420 , fol. $271 v^{\circ}-272$. 
buen canonista con aspiraciones era la carrera eclesiástica. Pues desde temprano intenta ya este camino: en 1730, 1731 y 1732 será nombrado por el arzobispo de Granada D. Francisco de Perea y Porras Examinador de los Colegiales del Señor San Miguel. Pero su carrera no tuvo siempre buenos resultados. Así en marzo de 1734 oposita a la canongía doctoral de Antequera quedando en segundo lugar; en febrero del 1735 a la doctoral de Almería consiguiendo sólo dos votos. En octubre de ese año al mismo cargo en Guadix, obteniendo un segundo lugar. En marzo de 1737 a la doctoral de Cádiz, sin resultado; en septiembre de 1737 a la de Toledo y con igual signo. En febrero del 38 a la canongía penitenciaria de Jaén en donde tampoco lo consigue, con iguales resultados que la doctoral de Córdoba en la que tuvo tres votos solamente. Pero no se debe caer en la consideración de que todos fueran fracasos. $Y$ es que en el año 1735 el obispo de Urgel le Ilama para Provisor de su mitra, cosa que Velarde no acepta. Lo que sí haría cuando siendo doctoral de Baza el obispo y cabildo de Murcia le ofrecieron una ración entera de esa Iglesia levantina. Siendo ya canónigo de Murcia, en 1752 fue nombrado Juez de Obras Pías del Obispado ${ }^{55}$.

Antes de terminar este apartado, se pueden recapitular algunos aspectos sobresalientes en esta familia. El primer aspecto que resalta a través de estas noticias es que el linaje Murillo Velarde de Laujar -entre el siglo XVII y XVIII- se distingue por la elevación profesional y social de un pequeño linaje, igual a otros muchos que en épocas anteriores y posteriores utilizaron sus cortos o modestos medios para escalar puestos de mando al servicio de la Monarquía. Aunque la ciudad de Granada, en el período estudiado, era una ciudad en decadencia, contaba, sin embargo, con importantes centros administrativos que facilitarian el cursus honorum de todos aquellos decididos a mejorar sus vidas.

De acuerdo con el ideal del príncipe cristiano, el Monarca debia acertar en la elección de sus ministros ya que, siendo un espejo para sus vasallos y para el Estado, en su persona se habían de encontrar «la religión, la justicia, la benignidad y las demás virtudes dignas del Imperio; y siendo parte de este espejo, los Consejos, Tribunales y Chanci-

55 Ibidem, Libro del Colegio Mayor de Santa Catalina y Santa Cruz (Libro Azul), fol. 184$184 v^{\circ}$. 
Ilerías, también en ellas se habían de hallar las mismas calidades, y no menos en cada uno de los ministros que le representan, pues una moneda pública es el ministro en quien está figurado el príncipe ${ }^{56}$.

Las mejores medios de selección de estos ministros, tanto para la Monarquía austriaca como para la borbónica, fueron las Universidades, sus Colegios y sobre todo las Facultades de Derecho y Cánones. Este camino fue aprovechado ya por el abuelo del jesuita, y por sus descendientes, pues igual daba servir al Rey desde las filas de lo laico o de lo eclesiástico. Además era más fácil poderlo hacer desde altos puestos en la Iglesia que en el mundo civil. Pero las Universidades y los Colegios, para elegir y cribar a los aspirantes utilizaron prontamente la limpieza de sangre, ya que se buscaba al noble o cuando menos al cristiano viejo, pese a que pensadores políticos como Baltasar Alamos de Barrientos en sus Aforismos al Tácito español dijera que tan sólo sería idóneo aquél "que vale en virtud y buenas partes de ánimo para el Gobierno público; y que tiene dada prueba bastante de ello por lo que no le ha de ser impedimento, para no llegar al supremo cargo de él, la bajeza de su casta» ${ }^{57}$. Por contra, es evidente que la limpieza de sangre se mantiene en la Universidad granadina pasado el siglo XVIII y que fue requisito indispensable ${ }^{58}$. Las informaciones producidas en estas probanzas, resultan de gran valor para la investigación histórica de los antecedentes familiares de la población estudiosa de esa época.

De ahí la importancia de que los Murillo Velarde sean considerados rancios cristianos viejos y nobles hijosdalgo, esto les permitiría sin graves conflictos obtener sus grados y adentrarse en la administración. De preferencia en la eclesiástica, donde el ascenso era más fácil, y no menos prestigioso. En esos tiempos en los que «Dios es el que

56 D. de SaAveora Fajardo, Idea de un principe político cristiano representada en cien empresas. Edición, prólogo y notas de Vicente García de Diego, Editorial Espasa-Calpe, Madrid, 1969, tomo II, p. 87, empresa XXXIII.

57 B. Álamos de BarRientos, Aforismos al Tácito Español. Estudio preliminar de J.A. Fernández-Santamaría, Centro de Estudios Constitucionales, Madrid, 1987, tomo I, p. 53.

58 Así el 2 de mayo de 1722 se ordenaba por el claustro que se le quitaran sus grados a Fernando del Castillo "notando al margen el referido decreto y motivo que habia para ello, de ser castigado por el Santo Tribunal de la Inquisición de esta ciudad en el auto de fe en el año 1721 », lo mismo le ocurria al Doctor Leonardo de Figueroa el 7 de febrero de 1728 por morisco. O a D. Miguel Fernández Girón por judío el 31 de mayo de 1702 que dejaba de ser licenciado en medicina. $Y$ terminando con el ejemplo, D. Diego Lamera malagueño que se matriculaba en medicina en 1701, hábil y suficiente, era quemado en el río Beiro de Granada por judio. A.U.G. 1440, sin foliar. 
gobierna los corazones, los anima y fortalece, el que da y quita las victorias", la Monarquía española se apoyaba en la lglesia para conservarse firme y segura como dice Saavedra Fajardo ${ }^{59}$. Por lo que no estaba mal servir desde ella al Rey y a Dios a la vez.

No serán en su mayoría los Murillo Velarde clérigos como los que quiso Francisco Ortiz de Salcedo para la Iglesia en 1626 en su Curia Eclesiástica, es decir, aquellos que en primer lugar atienden su obediencia a la Iglesia y al Romano Pontífice como su cabeza y sucesor de San Pedro no dando consejo, favor ni ayuda contra ellos, y advirtiendo y castigando, incluso al príncipe, si éste se opusiere a los deseos de la Iglesia ${ }^{60}$. Esto no quiere decir que los Murillo fueran serviles, sino que a través de la Iglesia, actuaban como servidores del Rey y de la Monarquía. Son agradecidos burócratas en busca del medro personal aunque de ellos se aparta el Padre Pedro Murillo Velarde y Bravo, que tuerce el camino que los suyos acostumbraron, pues en vez de seguir el sendero de su tío y hermanos, buscó una vía más peligrosa y menos honorífica, como fue su profesión en la Compañía de Jesús y sobre todo el camino de la misión. De esta manera, rompe hasta cierto punto los esquemas, y realiza una forma de vida extraordinariamente valiosa y una obra científica de relevante calidad en diversos campos.

Con esa libertad de espíritu, tanto frente a los prejuicios de su época, como frente a las aspiraciones tradicionales de su familia, será el colofón de un linaje de pequeños hidalgos provincianos que ascenderá al nivel de los caballeros a través de Obispos y Canónigos para tras ellos volver a la modestia de la provincia, un linaje que tiene su más preciada flor y fruto en la persona del jesuita Pedro Murillo, cuyo retrato finalmente se intentará esbozar.

\section{PEDRO MURILLO VELARDE Y BRAVO, APUNTES BIOGRÁFICOS}

Como se señaló al principio de estas páginas, un esbozo biográfico de Pedro Murillo Velarde y Bravo es cosa que resulta difícil, tanto por el carácter más bien panegírico de lo que sobre él quedó en las cróni-

59 D. de SaAvedra Fajardo, ldea, cit., tomo II, pp. 8 y 18.

60 F. Ortiz de Salcedo, Curia Eclesiastica. Imprenta de viuda de Alonso Martín, Madrid, 1626, Al lector. 
cas de su tiempo, como por lo poco o nada que posteriormente se ha recurrido a fuentes primarias sobre su vida.

El testimonio contemporáneo más notable sobre la existencia y obras de este jesuita, obligado recurso de quienes han intentado su semblanza, es el elogio fúnebre escrito por su hermano de hábito el $p$. Bernardo Pazuengos ${ }^{61}$; en él se han basado todos aquellos - tanto modernos como pasados - que han intentado realizar cortas biografías del jurista y religioso. Indudablemente que se trata de una fuente importante, pero limitada, que actualmente puede completarse con la nueva documentación que se ha recogido, tanto en archivos como en páginas autobiográficas que hallamos en sus escritos, especialmente en su singular Catecismo, lo cual permite una mayor aproximación a su entorno histórico y al curso vital de su persona.

Pedro Murillo Velarde y Bravo nace el 6 de agosto de 1696, en Laujar, aunque algunos lo hacen natural de Granada capital, siendo hijo de D. Jacinto Murillo Velarde y Ocaña y de doña Magdalena Bravo y Valdivia. Según su panegirista el padre Bernardo Panzuengos, cumplidos los tres años, es decir entre 1699 y 1700 sus padres trasladaron su morada a Granada de forma definitiva, lo que parece dudoso por las partidas de bautismo de sus otros hermanos datadas en Laujar. Fue sin duda un niño inquieto, por ejemplo el 10 de junio de 1700 librándose de la vigilancia de sus criadas tuvo un fuerte accidente que casi le cuesta la vida, que salvó por un lado gracias a la pronta intervención del cirujano y para el panegirista por la ayuda de la Virgen de las Angustias, Patrona de Granada ${ }^{62}$.

Estudió como era habitual con un maestro contratado por sus padres para que le ejercitase en el conocimiento de las primeras letras. Tras esta etapa sus padres lo entregaron a la tutela del citado Andrés Murillo Velarde y Fernández de Ocaña, el cual hizo que su pupilo ingresase en los colegios de la Compañía de Murcia y Toledo y se nutriese de los conocimientos de Gramática y Filosofía y en sus ratos libres del estudio de la Historia y de la Geografía. Aquí, en estos primeros contactos con la Compañía, puede estar la clave de su pos-

\footnotetext{
61 B. Pazuengos, Carta edificante, Cit. Igual pasa con su tío el obispo Andrés, de quien existe una oración fúnebre.

62 Por cierto que siempre será fervoroso devoto de la Virgen y de diversas advocaciones de la misma como la de Guadalupe, Antipolo, San Pedro Macali o Loreto
} 
terior incorporación a la misma y el abandono de una carrera similar a la de sus hermanos y que ya parecía haber emprendido.

Vuelto a Granada ingresa en el Colegio de San Miguel de la Universidad de Granada con la intención de conocer ambos Derechos. De allí pasó al Colegio Mayor de Cuenca, de la Universidad de Salamanca donde alcanzó el grado de bachiller en Sagrados Cánones. Según datos del Archivo de la Compañía de Jesús de Roma, Pedro había estudiado dos cursos de Filosofía y cuatro cursos de Teología, así como Derecho Canónico en el que consiguió el bachillerato ${ }^{63}$. En Salamanca, sorprendiendo por su juventud a todos, impartirá como profesor extraordinario Derecho Civil durante cuatro años ${ }^{64}$. Pero su carrera se corta al ingresar en el noviciado de los jesuitas de Madrid el 23 de octubre de 1718. A diferencia de sus hermanos, como estudiante en Granada no puede decirse que descollara, pues su carrera universitaria en la ciudad de la Alhambra no fue muy larga, ya que pronto se traslada a otras ciudades, ahora bien cuando ingresa de novicio en la Compañía ya le precedía la fama de sus días en Salamanca ${ }^{65}$.

Al año siguiente en 1719 pasa al Colegio jesuita de Alcalá de Henares donde estudia Filosofía y Teología. De vocación misionera y devoto seguidor de San Francisco Javier solicita destino en Filipinas, lo que hace entre 1722 y 1723. Año, el último, en que se traslada a la remota provincia jesuítica aprovechando el viaje realizado, a instancias del General padre Tamburini, por el criollo de Santafé de Bogotá padre Juan Antonio de Oviedo en calidad de Visitador de la Provincia Filipina ${ }^{66}$. De Acapulco parte el Visitador el 10 de marzo de 1723, acompañado por Pedro Muri-

63 Archivo de la Compañia de Jesús de Roma (en adelante A.R.S.1.), Congre.4No.es, Philip. 3, $1{ }^{\circ}$ Catálogo de personas de la Compañía en Filipinas de 1725, fol.168.

64 A.R.S.I., Congre.4No.es, Philip. 3, Catálogo de las casas de la Provincia de las Islas Filipinas comenzado en 1725, fol.200.

65 La ruptura de la carrera de Pedro Murillo Velarde y Bravo con respecto a las seguidas por sus familiares es tajante, de tal modo que puede encerrar inclusive algún enfrentamiento. Lo cierto es que parece que las relaciones del jesuita y de sus parientes cuando menos se enfriaron, en especial en lo que a su tío obispo se refiere. De este modo en el juicio hecho al Cursus por el reverendo padre maestro Diego de Quadros, antiguo profesor de Murillo, se llega a expresar: "Dei impulsu a mundiali pompa fugitivo, et a patruo suo, Cuisque charissimus vere fugiente, ad Tyrocinium Societatis Jesu... celerrimus convolavits. Vid. p. MURILLO VELARDE, Cursus Juris Canonici Hispani et Indici, tomo I, 3 edición, Madrid, 1791, Judicium R.p. M. Didaci de Quadros.

66 Vid., P. A. Astrain. Historia de la Compañia de Jesús en la asistencia de España, Administración de Razón y Fe, Madrid, 1925, Tomo VII, p. 555 
Ilo Velarde, el que arriba a Filipinas el día 27 de octubre de 1723 en calidad de teólogo ${ }^{67}$. Allí comienza a trabajar para la Compañía como operario, misionero y teólogo, pero aunque ocupa en sus inicios y como era preceptivo, según su nueva situación, los empleos más bajos y de inicio en la provincia filipina de los jesuitas, su fama le acompaña y pronto demuestra sus capacidades. En el segundo catálogo de las personas de la Compañía comenzado en 1725, se dice de su naturaleza lo siguiente:

“Ingenium: bonum. ludicium: bonum. Prudentia: bona. Experientia: mediocris. Profectus in litteris: bonus. Naturalis complexio: colerica» ${ }^{68}$.

Por todo ello es considerado como una óptima adquisición para la Compañía en Filipinas, expresándose:

"Ad qua ministeria talentum habet: ad omnia ministeria societatis" 69.

Aunque viajó y tuvo a su cargo diversas ocupaciones por todas las islas y territorios, por ejemplo en 1725 estaba en San Pedro Macali posiblemente como vicerrector, lo cierto es que su existencia estuvo muy ligada al Colegio de la Compañía en Manila, allí residía en 15 junio de 1727, estando encargado de impartir clases de Derecho Canónico ${ }^{70}$. Manila sin duda le deslumbra y pese a las críticas a su sociedad, la ciudad, como tal, en su estructura y en la variedad de mundos que encierra absorve su interés. Se siente orgulloso de ella y más aún de la sede jesuítica que reside en la capital del archipiélago:

"Los edificios más suntuosos son las iglesias, los conventos y Colegios. El de la Compañía es bien grande y en él hay Universidad, concedida por el Papa y por el Rey, en que se leen dos Cáthedras de Theología, una de Cánones, otra de Instituta Civil, otra de Filosofía y Gramática

67 A.R.S.I., Congre.4No.es, Philip. 3, Catálogo de las casas de la Provincia de las Islas Filipinas comenzado en 1725 , fol. $184 \mathrm{v} .^{\circ}$. El citado Astrain le hace llegar a Manila, quizá por error y en contra de lo que resulta de la documentación del Archivo romano de la Compañía, el 30 de junio de 1723, tras peligroso viaje y una larga espera en las Islas Marianas, Op. Cit., p. 555.

68 A.R.S.I., Congre.4No.es, Philip. $3,2{ }^{\circ}$ Catálogo de personas de la Compañía en la Provincia de Filipinas comenzado en 1725, fol.178.

s9 lbidem.

70 A.R.S.I., Fondo jesuita 630 , Catálogo breve de las personas de la provincia filipina realizado el 15 de junio de 1727, siendo provincial Pedro de las Heras. 
y escuela de leer, escribir y cantar. Hay en dicho Colegio, imprenta y botica. La iglesia es la más bella, la más bien hecha, la más fuerte, la más magnífica y de mejor arquitectura que, creo, tiene la Compañia en todas las Indias... Inmediato está el Real Colegio de San Joseph, a cargo de la Compañía, en él estudian Gramática, Filosofía, Teología y Cánones y Leyes los colegiales que son siempre de lo más noble y selecto de las Islas. Felipe $\mathrm{V}$, el año de 1722 , le confirmó el título de Colegio Real y tiene sobre su puerta las armas reales de España" ${ }^{7 !}$.

En 1730 publica en español el librito-relación de la fiesta que hizo el Colegio de Manila por la canonización de San Estanislao Kotska y San Luis Gonzaga 72.

En el año de 1732 desembarca en Filipinas un escolar jesuita que estará inevitablemente unido a Pedro Murillo Velarde, su biógrafo y panegirista, Bernardo Pazuengos. Éste había nacido en Guernica, diócesis de Calahorra el 22 de mayor de 1706 e ingresó en la Compañía el 3 de octubre de 1720, profesando de cuatro votos, ya en Filipinas, el 15 de agosto de 1739. Su vida como se apreciará estuvo bastante ligada a Murillo, aunque el final de ella fue muy distinto, pues siendo Rector del Colegio de San Ignacio de Filipinas fue expulsado, junto a los demás sus compañeros, embarcando para el exilio en la fragata Santa Rosa. Final diverso pues cuando moría Pedro Murillo Velarde, la Compañía, pese a sus detractores, aún existía llena de plenitud. Pero no se adelanten los acontecimientos. En el año de llegada del padre Bernardo Pazuengos, 1732, Murillo da a la imprenta su exitosa Práctica de Testamentos (De testamentis) ${ }^{73}$.

71 P. Murillo Velarde, Geographia histórica de las Islas Philipinas, del África y de sus islas adyacentes. Imprenta de Gabriel Ramírez, Madrid, 1752, tomo VIII, p. 53. La iglesia del Colegio de Manila que tanto admira «la consagró el año de 1727 , el día veinte y siete de julio, el ilustrísimo señor doctor don Phelipe de Molina, obispo de Nueva Cáceres, y le asistimos el padre Juan Antonio Cantova, que después murió por Cristo en las Islas Carolinas, y yo", Ibidem. Historia de la provincia de Filipinas de la Compañia de Jesús. Segunda parte. Comprende los progresos de esta provincia desde el año de 1616 hasta el 1716. Imprenta de don Nicolás de la Cruz Bagay, Manila 1749, fol.197v. ${ }^{\circ}$. Con respecto del también elogiado Colegio de San José hay que comentar que en vida de Murillo no siempre pasó por épocas de bonanza. El Rey tuvo que mandar, desde su palacio del Buen Retiro el 26 de septiembre de 1747, que se le prorrogase el goce de la encomienda que poseía sobre los pueblos de Sulal y Tubig, de la provincia filipina de Leyte, "para que pueda subsistir el Colegio de Padres jesuitas de San Joseph de Manila y reparar los daños que ha padecido en el levantamiento de los Yndios de Balayan", Archivo General de Indias (A.G.I.), Filipinas, Leg.97.

72 A.R.S.I., Congre.4No.es, Philip. 3, Catálogo de las casas de la Provincia de las islas Filipinas comenzado en 1725, fol.192.

73 lbidem, fol. 194. 
Otro año importante en su vida es el de 1734, publica su Charta Chorographica Insularum ${ }^{74}$, realizada por encargo regio y muy utilizada en adelante por marinos y navegantes ${ }^{75}$, pero lo es sobre todo por su compromiso definitivo de iure con la Compañía de Jesús al profesar de cuatro votos el 24 de octubre de 1734:

"Ego Petrus Murillo Velarde profesionem facio, et promitto omnipotenti Deo, coram Virgine Matre, et universa caelesti Curia, ac omnibus circumstantibus et tibi Rev. Patri Josepho Astudillo, Provinciali Philipinensi, R.p. Francisco Retz, praepositi generali Societatis Jesu et successoribus eius locum Dei tenenti, perpetuam paupertatem, castitatem et obedientiam et secundum eam peculiarem curam circa puerorum eruditionem; iuxta formam vivendi in Litteris Apostolicis Societatis Jesu, et in eius Constitutionibus contentam. Insuper promitto specialem obedientiam Summo Pontifici circa missiones prout in eisdem Litteris Apostolicis et Constitutionibus continetur. Manila in ecclesia Colegii. S.p. N. Ignatii. Die, vigesimaquarta, octobris. Anno millesimo septingentesimo trigesimo quarto. Joseph Astudillo. Petrus Murillo Velarde" ${ }^{76}$.

Su carrera en Filipinas indudablemente se debe a sus propios méritos, pero esto no es obstáculo para certificar que próximo a ella estu-

74 Ibidem.

75 "Murillo was, like Klein, a man of many parts. He was not only a cronist and historian, but a cartographer of some distinction. His interest in subject must have been well known in Manila, for, when a royal order came in 1733 calling for a map of the Philippines wich would incorporate the latest available information, it was to him that Governor Valdés Tamón entrusted the project. The completed map was engraved the following year in the college printing by Nicolás de la Cruz Bagay. Up to end of the eighteenth century it was the standard map referred to in admiralty proceedings, and later cartographers reproduced it winth only minor changes and often without acknowledgment", en P. H. de la CosTA, The Jesuits in the Philippines, 1581-1768. Harvard University Press, Cambrige-Massachusetts, 1961, p. 567.

76 A.R.S.1., Hisp. 28-I, Protesión de cuatro votos de Pedro Murillo, fol.120-120v. ${ }^{\circ}$. dada la importancia del documento se presenta a continuación la traducción del mismo. Traducción que debo agradecer, entre otras cosas, a mi gran amigo y profesor el Dr. Alberto Carrillo Cázares, que también ha supervisado con paciencia ilimitada la corrección de los textos latinos que contiene el presente estudio. "Yo, Pedro Murillo Velarde, hago profesión y prometo a Dios, Padre Todopoderoso, delante de la Virgen Madre y de toda la corte celestial, y ante todos los presentes y ante tí, Reverendo Padre José Astudillo, Provincial de Filipinas, y ante el Padre Francisco Retz. Prepósito General de la Compañía de Jesús, y sus sucesores, que ocupan el lugar de Dios, perpetua pobreza, castidad y obediencia, y conforme a ésta, particular dedicación a la educación de los jóvenes; según la forma de vida que se contiene en las Letras Apostólicas de la Compañía de Jesús y en sus Constituciones. Prometo, además, especial obediencia al Sumo Pontífice en lo que toca a las misiones, según se contiene en las mísmas Letras Apostólicas y Constituciones. En Maníla en la Iglesia del Colegio de Nuestro Padre San Ignacio, el día veinticuatro de octubre del año de mil setecientos treinta y cuatro. José Astudillo. Pedro Murillo Velarde". 
vo siempre el arriba nombrado padre José Astudillo, que además de Provincial ocupó numerosos cargos en Filipinas así como fue procurador de la Provincia en Madrid y Roma. Pues bien, por su intercesión es designado visitador de las misiones de Samboang y Dapitán el 15 de octubre de $1735^{77}$. Y junto a Astudillo, que era en esos momentos Provincial, aparece como su socio -especie de secretario en terminología de la Compañía - en la misión de San Miguel sita en los suburbios de Manila en 1737. Allí se dedicarán los jesuitas a atender a indios y otros naturales, al igual que a atraer y congregar a los indios infieles que dispersos vivían en las montañas:

"In hoc altero Manilano suburbio moratur p. Josephus Astudillo, provincialis, cum suo socio $p$. Petro Murillo Velarde, et insuper operam dat saluti Indorum, aliarumque nationum, $p$. Philippus Solís, $p$. Pedro de San Lucas, Antonius Raucher. Incumbunt etiam in colligendo infideles indos dispersos in conterminis montibus" ${ }^{78}$.

En esa casa, en Manila, Pedro Murillo Velarde será por los años de 1737 a 1742 profesor de prima de Teología, estando acompañado por su ya amigo Bernardo Pazuengos que ocupaba en 1739 la plaza de profesor de Filosofía ${ }^{79}$. En 1742 participará en la XXIII Congregación Provincial de la Compañía en Filipinas para la elección de nuevo provincial, Congregación que tendrá fin el 21 de mayo siendo nuevo provincial el padre José Javier de Samaniego ${ }^{80}$. En 1743 sigue en la ciudad de Manila como profesor y viviendo en la casa misión, teniendo como superior a Astudillo:

"In Manilana missione quindecim Missionarii numerantur ex nostris, qui Hispanorum et Indorum, Etioporum, aliarumque nationum saluti incumbunt. Eorum nomina haec sunt: Josephus Astudillo, superior. $p$. Agustinus Baeza, $p$. Petrus José de Zisa, p. Francisco Merckel, p. Petrus Murillo, p. Martin Yrisarri, p. Petrus Tavernier, p. Josephus Chacón, Antonio Raucher, Antonio Lozano, Manuel José Avendaño, José Torres, Phelipe Mesia, Fernando de Haro, Miguel Quirós" ${ }^{81}$.

77 A.R.S.I., Congre.4No.es, Philip. 3, Catálogo de las casas de la Provincia de las Islas Filipinas comenzado en 1725, fol. 200.

78 Ibidem, fol. 217.

79 A.R.S.I., Congre.4No.es, Philip. 3, Catálogo de las casas de Filipinas comenzado en 1737, fol. $247-247 v$. .

${ }_{80}$ Ibidem, Congregación Provincial, 90. Filipinas, 1742, Congregación XXIII, fol. 219-221v. .

81 Ibidem, Congre.4 No.es, Philip. 3, Catálogo de las casas de Filipinas comenzado en 1737, fol. 260 . 
La actividad académica sobresalió sin duda en su vida, en 1745 ocupaba la plaza de Cánones, pero esta vida adquiere un giro cuando en 1746 es destinado a la Misión de Antipolo. Abandona su querida Manila y se traslada a su nueva residencia en donde ocupará los últimos años de su vida en las Islas Filipinas. En documento datado el 20 de noviembre de 1749 consta una suscinta descripción de la misión y de sus misioneros:

"Missio Antipolane. Oppida quinque haec missio numerat: Antipolo, Taytay, Crinta, S. Matheum et Boroboso totidemque pp. Yhs. Spiritualiter - subveniunt. Pater Petrus Murillo, superior. p. Isidoro Armendaris, José Silvestri, ${ }^{82}$.

En 1749 nuevo cambio a su variada existencia. Se celebra una tormentosa reunión provincial de los jesuitas en el Colegio Máximo de Manila. Se trata de la Congregación XXIV de la Provincia de Filipinas. El 20 de mayo de 1749 a las ocho de la mañana se realiza la primera sesión, Murillo Velarde -rector de Antipolo- no es convocado. Sí lo será a la segunda sesión. Durante la Congregación se discuten varios asuntos: uno de ellos la elección de nuevo provincial. La situación se enrarece. El provincial saliente, Samaniego, solicita a los asistentes una prórroga a su mandato. La petición está en contra de la tradición y costumbre jesuítica de aquellas provincias, el resultado es que no prospera. La votación secreta en vez de dar un aplazamiento a Samaniego, reelige -pues lo había sido ya antes-como Padre Provincial de Filipinas a José Astudillo. El cargo esta vez le duraría poco, pues José Astudillo moría en Manila el 12 de agosto de 1749. No obstante esta elección precipitaría el giro comentado en la vida de Pedro Murillo Velarde, el que como se ha puesto de manifiesto era casi hechura de Astudillo. De esta manera durante la segunda sesión de la Congregación XXIV se pasa a votar quiénes serian los procuradores en Madrid y Roma. Son designados Murillo y Pazuengos: Murillo Velarde como primer Procurador Provincial ante las Cortes de Madrid y Roma, y Bernardo Pazuengos como segundo Procurador Provincial ${ }^{83}$ :

"factaque brevi oratione, acta sessionis praecedentis lecta fuit, et omnibus approbata. Tunc a R.p. Provinciali, procuratorum electio omnibus

82 Ibidem, fol. 309v. ${ }^{\circ}$

83 A.R.S.I., Congregación Provincial, 90. Filipinas, 1749, Congregación Provincial XXIV, fol. 213-234. 
indicta ad plura medietate sufragia secreta, iuxta paragraphum 28 formulae, in secundo scrutinio Pater Petrus Murillo Velarde, rector residentiae Antipolanae est renuntiatus ${ }^{84}$.

Marcha a Europa, hacia la metrópoli, no por el camino habitual, atravesando México, sino que realiza el viaje bordeando África. Viaje, como casi todos los de la época, azaroso pero feliz pues se llega al puerto ansiado. No obstante en los relatos que hace describiéndolo, por ejemplo en el Catecismo, se aprecian las penalidades que se sufrieron y en fin, siempre que se refiere a los viajes marítimos, ya sean transatlánticos o de cabotaje entre las Islas Filipinas, se vislumbra su poca afición al mar y a este tipo de viajes.

A su llegada a Europa, le esperarán importantes misiones y también emotivos viajes así como alguna tentación $-\mathrm{y}$ es que volviendo de Roma por Barcelona tuvo que rechazar el grado de doctor en ambos Derechos que le ofrecía la Universidad de Cervera, a cambio de que se quedase allí como catedrático y abandonase su vida anterior-. Pero, por encima de todo, ésta es la etapa de hombre político, que siempre fue, pero que desarrolla su actividad ante las más altas instancias civiles y eclesiásticas. Correosos funcionarios de todo tipo y trabas se le interpondrán, pero eso no será obstáculo para que el procurador provincial filipino Murillo Velarde intente llevar a cabo sus objetivos. Fines que no son otros que mediar a favor de la Compañía, de las Indias y especialmente y en particular conseguir beneficios para sus Filipinas y para la Provincia Jesuita de las Islas. Estas ayudas, estos pretendidos beneficios que ruega son muy diversos, pero sobre ellos destaca la necesidad imperiosa de reclutar nuevos jesuitas para las Filipinas y medios con que sostenerlos ${ }^{85}$. Esto solicitará al Rey y al Papa. En el caso del

\footnotetext{
84 Ibidem, fol. $215 \mathrm{v} .{ }^{\circ}$.

85 "Si todas las provincias ultramarinas necesitaban el auxilio de misioneros europeos para sostener las grandes empresas apostólicas acometidas para la conversión de lo infieles, esta necesidad se hacía sentir todavía más en Filipinas, donde siendo tan reducida la población de españoles, escaseaban por lo mismo las vocaciones al estado religioso. No fueron cortos nuestros procuradores de Filipinas en pedir refuerzos de misioneros, y ni el Rey de España ni los jesuitas españoles dejaron de atender a los deseos de tan benemérita provincia", A. Astrain, Historia, cit., p. 738. Como simple indicativo de los documentos analizados en A.R.S.I. se decantan las siguientes cifras del número de jesuitas de Filipinas que deben tenerse siempre en relación con lo grande de la extensión y de la población de la provincia filipina que la Compañia tenían que custodiar: Año 1725: 157 jesuitas/1731: 131/ 1732: 172/ 1733:172/ 1734:172/ 1735:172/ 1736:172/ 1737:121/ 1743:92/ 1744:130/ 1745:130/ 1746: 130/ 1749:122/ 1768:143.
} 
primero, del Monarca, consta que aunque no alcanzó todo lo que quería, lo intentó y consiguió algo, según un memorial y petición del Consejo de Indias al Rey datado el 12 de abril de 1752, fecha cercana a la muerte de Pedro Murillo, documento que dice asi:

«Señor. El padre Pedro Murillo Velarde, de la Compañía de Jesús, y Procurador General de su provincia de San Ygnacio de las Yslas Philipinas; ha representado la necesidad con que se halla de sugetos para poder administrar las misiones y ministerios que están a cargo de la misma Provincia. Como consta de los informes que ha presentado del Governador y Arzobispo de aquellas Yslas y que eso sólo no tiene en cada pueblo dos sacerdotes para la más fácil administración, como están en el Paraguay y en otras misiones, sino que muchas vezes ha de cuidar un misionero de dos o más pueblos por la falta de sugetos y siendo muchos los ministerios a que según su Instituto deve atender la Compañía y haver sabido el expresado procurador que después de su salida de Manila han fallecido en breve tiempo ocho jesuitas. Suplica a Vuestra Majestad que aunque para socorrer la necesidad presente se requiere sesenta operarios, no pudiendo su Provincia costear su transporte, sin embargo de concurrir Vuestra Majestad con sus socorros, se sirva de conceder la misión de quarenta religiosos en forma acostumbrada» ${ }^{86}$.

Estando en Roma, un año antes del citado memorial al Rey, igualmente además de interceder ante sus superiores, ante el Colegio de Cardenales y ante el mismo Papa por sus misiones filipinas y por las Indias en general, participará en la Congregación General XVII de la Compañía de Jesús celebrada en el año 1751 y que tenía entre otras finalidades elegir un nuevo Prepósito General, sin duda la ocasión más significada como sacerdote jesuita de Pedro Murillo Velarde. En las actas de dicha Congregación General aparece en el folio trece vuelto como uno de los electores, constando que era Procurador Provincial de las Filipinas y que a la sazón tenía cincuenta y cinco años. En el siguiente folio, catorce, otro jesuita de las Filipinas, Bernardo Pazuengos, de cuarenta y cinco años y por entonces rector de San Ildefonso en las Islas y su segundo Procurador Provincial. Durante la Congregación XVII, el General de la Compañía instituyó varias comisiones de trabajo, entre ellas, la segunda, denominada "Pro constitutionibus, De-

86 A.G.I., Filipinas, I_eg. 97. Puede que la expedición de 23 religiosos jesuitas destinados a Filipinas en 1753 que refiere el padre Antonio Astraim fuera la respuesta a esta petición. Lo que parece inexacto es que los acompañara Murillo Velarde como dice Astraim, pues al poco moría nuestro jesuita en el Puerto de Santa María. Vid., P. A. Astrain, Historia, cit., p. 739. 
cretus et Ordinat. General'. Comisión en la que participó Pedro Murillo Velarde, teniendo un papel destacado y transmitiendo sus ideas y peticiones para la mejora de las misiones de Indias y Filipinas:

“Tum tria alia postulata breviter exposuit R.p. Nr. in quorum p. Petrus Murillo Velarde rogabat ut Catholico Hispaniarum Regi... Primis quidem duobus pro nuperrimine isque maximis beneficiis nostrae Societati collatio nedum in omnibus Hispaniae Regnis, ac in Lusitania; sed Indicis etiam missionibus, aut auctis, aut de novo erectis in IIS provinciis utriusque Regnis dominio subjectis" ${ }^{87}$.

Aunque consiguió parte de sus propósitos, Pedro Murillo Velarde no conseguiria volver a sus Filipinas. Sufriendo algún tipo de enfermedad psíquica - melancolía dicen los textos-, muere en el Puerto de Santa María - actual provincia de Cádiz en España - en el Hospicio el 30 de noviembre de 1753, cuando se disponía a embarcar ${ }^{88}$. La distancia y la tardanza de Pazuengos en regresar a Filipinas -parece que intentó quedarse en la Nueva España- seguramente produjeron que sus compañeros jesuitas lo siguieran teniendo por vivo en 1753, pues de ese año se realiza un listado en 1754 de los jesuitas que pertenecían a la Provincia y en él con el número 34 aparece Murillo Velarde, con una nota al margen en la que se indica que es procurador en Roma y Madrid. Entre la confección de este listado de 1753 y el siguiente de 1754 efectuado en 1755 les llegó la noticia de su defunción pues en este último padrón de los jesuitas de Filipinas ya no se encuentra al biografiado. Terminaba así su existencia para sus compañeros de vicisitudes y misionado, no obstante su memoria estaría siempre presente en ellos y sus sucesores ${ }^{89}$.

Su vida, como hasta aquí se ha relatado, fue intensa: estudiante en Granada y Salamanca, jovencísimo profesor extraordinario en la última Universidad. En Filipinas, Catedrático de Filosofía, de Teologia, de De-

\footnotetext{
${ }^{87}$ A.R.S.I., Congregaciones Generales, Congregación General XVII, fol. 71-71V. .

88 «ll venait de terminer sa mission et attendait, dans la résidence de la Compagnie à Puerto de Santa-María, le départ des vaisseaux pour retourner aux Philippines, lorsqu'il plut à Dieu de rappeler à lui son fidèle serviteur. Le $p$. Murillo était âgé de cinquante-sept ans, il en avait passé trente-cinq en religion et trente dans !a mission des Philippines", en E. de GUIL Hermy, Ménologe de la Compagnie de Jésus, Assistance d'Espagne, Troisiéme Partie. Typographie M.R. Leroy, París, 1902, p. 496.

${ }_{89}$ A.R.S.I, Congre. 4No.es, Philip. 3, Catálogo de las casas de la Provincia de las Islas Filipinas comenzado en 1725 , fol. 315 .
} 
recho Canónico, socio del Provincial Astudillo, misionero o simple operario, rector de Antipolo, visitador, vicerrector de San Pedro Macali. Por encargo del Santo Tribunal de la Inquisición, censor de las obras literarias que llegaban a Manila por manos de los comerciantes que arribaban a sus puertos, lo que sirvió para que fuese nombrado Calificador del Santo Oficio, y para que durante su estancia en España fuera utilizado por el Consejo de Castilla para realizar la censura de algunos libros ${ }^{90}$, por último Primer Procurador Provincial de las Islas Filipinas de la Compañia de Jesús ante las Cortes de Madrid y Roma, viajero incansable, etc. Pero pese a lo dicho hasta aquí, Pedro Murillo Velarde, sobre cualquier cosa, fue un sacerdote jesuita y un hidalgo de raigambre tradicional metido a erudito, convertido en jurista e intelectual. Pero todo en servicio de Dios y del Rey y cómo no, de la Compañía de Jesús y de las Filipinas.

Hasta aquí su vida en hechos, seguramente faltan otros muchos, pero no cabe duda que lo que va relatado sitúa suficientemente a la persona en su desarrollo vital. Pero todo estaría incompleto si llegado este momento aquí se terminase. Queda mucho que investigar y que decir sobre Murillo y es deber de quien escribe intentar acercarse a la persona, no sólo a sus hechos.

\section{ASPECTOS DEL PENSAMIENTO DE MURILLO VELARDE}

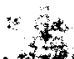

induterblemente $-y$ admitiendo que la Historia, como cualquier otra discibina representa retos y obstáculos a veces difíciles o imposibles de salvăr - es necesario ir más allá de los hechos, con el peligro que esto representa, para conocer mejor. Para buscar la verdad. Pues bien, si esto ocurre en la Historia en general, a veces cuando se adentra el investigador en alguna de sus especifidades, como puede ser la biografía, el estudio de una persona concreta, su conocimiento, pasados

90 El gran bibliófilo español Aguilar Piñal al hacer referencia a Murillo Velarde cita como ejemplo de su actividad de censor las siguientes obras, que pueden servir de muestra de la que debió desarrollar en su conjunto Murillo Velarde: realiza la censura del sermón de fraile filipino José Torrubia titulado "Sermón panegyrico que el último día de los tres con que la Hermandad de la Santa Misericordia celebró el cumplimiento del siglo de la colocación de la admirable imagen del Santísimo Christo de la misericordia en su iglesia de la ciudad de Manila», o la del libro de José Antonio Aguirre, hecha en Madrid a petición del Consejo, titulado Vuelta al mundo de $G$. Anson en 1740-1744. 
los hechos e intentando comprender a la persona, se corren graves riesgos que se pueden resumir en la extralimitación. Pero ellos no justifican en ninguna manera que se obvie cómodamente este fielato, se debe intentar llegar a la persona, a su interior, a su pensamiento, aunque sea someramente. Eso si, teniendo siempre presente que nunca puede ser algo más que una aproximación pues, si nosotros mismos nunca llegamos a conocernos enteramente y de vez en cuando nos sorprendemos, resulta meridiano que acercarse a otra persona intentando conocerla y comprenderla en su ser y más cuando lleva muerta casi tres siglos es casi imposible. Sin embargo hay que intentarlo, aprovechando no sólo sus pensamientos sino también sus hechos y las circunstancias que lo rodean.

En consecuencia, vista esquemáticamente su vida y de acuerdo con las fuentes, se pueden apreciar tres rasgos destacados y sobresalientes de su personalidad, una personalidad compleja y contradictoria, por otra parte. Uno es su entrega al apostolado misionero, otro el ejercicio de su vocación científica, como jurista, historiador, geógrafo y teólogo, y el tercero su sentido del deber y su gran capacidad de trabajo.

Pedro Murillo Velarde es, primeramente un hombre entregado a su vocación religiosa. En esta perspectiva, su profesión en la Compañía de Jesús es fundamental para encuadrar su vida y su obra. Es un sacerdote que quiere servir sinceramente a Dios, sin deseo de medrar ni favorecer a su familia, alejándose de intereses triviales y comprometiéndose al apostolado misionero, nada tiene que ver en este sentido con su tío el obispo Andrés o con su padre o abuelo, aunque como humano que es, sepa y esté orgulloso de su propia valía. Podría haber seguido la carrera de sus hermanos, pero eso no es lo ansiado por Pedro Murillo, su objetivo está marcado en la cruz que cada uno debe imponerse para servicio de Dios y de los hombres. Es un fiel católico y un jesuita convencido. Al servicio de esta vocación pone su inteligencia, cultura y capacidad de trabajo, con una mentalidad, a veces, notablemente abierta, frente a prejuicios usuales de su época ${ }^{91}$. En prin-

91 Por ejemplo durante la Edad Moderna e incluso durante el siglo xix español -recordemos a fray Diego José de Cádiz y su influencia a finales del setecientos y en los inicios del ochocientos en España- las fiestas, bailes y juegos fueron punto de discordia entre la ortodoxia más pura contraria a ellos y otros religiosos que diferían de esta postura. Este último es el caso de Murillo Velarde que en todos sus escritos defiende la actividad moderada de estas manifestaciones de esparcimiento. $Y$ es que además de santificar las fiestas, "también con- 
cipio sabe distinguir la diferencia de los diversos mundos a donde pasa y admirar su belleza, pero también advierte los defectos que piden remedio, desde su óptica misionera. Así lo relata él mismo a sus hermanos de la Compañía de Alcalá de Henares en una carta desde Filipinas - fechada en San Pedro Macali el 13 de junio de 1725- enviada con los padres José de Bovadilla y Buenaventura Plana, que pasaron a Madrid y Roma como procuradores provinciales, donde no duda en afirmar: "Solamente para trabajar por Cristo es aqui la esfera muy dilatada» ${ }^{92}$. Recién llegado, lleno de ilusiones, ansioso de ofrecer la vida en la primera oportunidad por la mayor gloria de Dios, como se desprende del siguiente párrafo:

"Luego que llegamos a las Islas se embió una armada a Sanboanga contra los moros que infestaban aquellas costas. $Y$ aviendo pedido el Governador dos padres de la Compañía para capellanes, y deseando yo optar tan buena ocasión me ofrecí para esta jornada. $Y$ hubiera ido ciertamente, si no fuera por estar ocupado con los estudios y aunque propuse interrumpirlos o dejarlos no me lo concedieron. Fue el padre Juan Anglés, que pasó por este Colegio poco después que yo salí de él. Se halló en la frente de nuestros soldados con un Santo Christo en la mano cuando en Tuboc dieron la batalla a los moros y después trabajó gloriosamente por aquellas islas colectivizando gentiles y bautizando a muchos" ${ }^{93}$.

viene ocuparse en alguna diversión decente: en visitar a los amigos, pasearse en el campo, divertirse en algunos juegos o particulares o públicos, no peligrosos, en correr cavallos, cañas, sortija, estafermos, jugar a la pelota, o los bolos, trucos, tirar a la barra, jugar las damas o tablas $\mathrm{o}$ al axedrez o a los naypes por diversión y moderadamente. La música es una diversión muy decente... El labrador alivia su trabajo cantando, el que navega, alivia cantando su peligro, el pastor, cantando alivia la soledad. Todos en fin allan diversión en la música... los bayles como sean con la debida simplicidad y decencia, que se hazen en las aldeas entre rústicos sencillos o en las ciudades entre gente honrada y política, se pueden permitir. Pero no aquellos en que las cancicnes deshonrosas, los gestos y movimientos lascivos y sobre todo la calidad de los concurrentes provocan el vicio y el pecado... Las danzas españolas son de más arte y más delicadez que las extranjeras y sobre todo son más puras y más honestas, sin que haya tocamiento de manos y brazos", MURILLO VELARDE, Catecismo o instrucción christiana en que se explican los mysterios de nuestra Santa Fe. Y se exhorta a huir de los vicios y abrazar las Virtudes, Imprenta de los herederos de Francisco del Hierro, Madrid 1752, p. 149-150. Igualmente en su Cursus, en el libro III, título I, al hablar de la honestidad de los sacerdotes, recuerda con satisfacción la fiesta mayor de su Granada: «En nuestra España se mezcian al coro de los cantores, hombres enmascarados, personajes gigantes o fingidos y van saltando en las procesiones que se hacen en la festividad del Corpus Christi... Esto se conserva en España y principalmente en la ciudad de Granada, donde esta fiesta se celebra de modo admirable y casi con una magnificencia y solemnidad increibles".

92 Archivo de la Provincia de Toiedo de la Compañía de Jesús (en adelante A.P. T.S.I.), E-2: 98, 13. Carta del padre Pedro Murillo Velarde, 1725.

93 Ibidem. 
Su inteligencia y curiosidad le hacen inmediatamente enamorarse de su nuevo país como lo delatan estas líneas del jesuita que hablan de sus Filipinas, no obstante la relación al final será casi de amor-odio:

"El que fuere zeloso puede ser apóstol de todo el mundo, pues todas las naziones de él acuden a estas Yslas. Son los tagalos, raempangos, pangasmanes, camarines, ylocos, capayanes, aetas, zambales, mardicas, ygarrotes, bissayas, lutaos, subanos, mindanaos y otros muchos. Pues apenas ay ysla en donde no aya variedad en lengua y costumbres. Fuera de esto, ay aqui de todas las naciones de Europa y de la América. Avrá como veynte mil chinos o sanpleyos. Bien vienen aquí por la vía de Oriente: persas, arnanios, tártaros, mogoles, cambayos, macassones, baneyes, malacos, goanos, mozambiques, lascares, maliapures, griegos, turcos, malabares, ay muchos cáfres y otras castas de negros. Es cosa divertidisima la gran variedad de trages, lenguas, turbantes, ritos y ceremonias" ${ }^{94}$.

Su admiración es, también, por su riqueza natural, de las Islas, y por algunas de sus poblaciones, recuérdese Manila -como ejemplo de gran ciudad-o el siguiente tratamiento que hace de un pequeño pueblo como Quipayo:

"este es el pueblo más hermoso que yo he visto en las Islas. Las calles son largas, anchas, derechas, tiradas a cordel y muy iguales. Las sementeras están divididas en quadros y cercados por todos ellos de cocos, puestos a cordel, altos y derechos que hace una vista hermosísi$\mathrm{ma}$, de que si estuviera en Francia habría ya varias láminas» ${ }^{95}$.

Posee indudablemente un ansia de conocimiento innata por todas las cosas y por muchísimas materias, lo que produce que registre en sus obras costumbres o hechos de su nueva patria que le llaman la atención y chocan con su forma de pensar, aunque no sean realmente importantes, por ejemplo:

«También los españoles usan mucho el baño en Manila, por el calor del pais, para templar la sangre y librarse de tabardillos, garrotillos y otros accidentes. Los españoles de la tierra se bañan todo el año, a modo de ranas, tienen un color tan pálido y tan exagüe que parecen figurillas" 96 .

95 P. Murillo Velarde, Geographía Histórica de las Islas Philipinas, cit., pp. 62-63. 
Pero es un sacerdote comprometido, que por encima de todo está convencido de que el misionero ha de ir soportando su cruz, como el San Andrés de su sermón, para ganar cada día más fieles para Dios. Es la cruz que defiende del siguiente modo:

"Sí señores, no podemos vivir sin Cruz y nuestra felicidad está en saberla escoger. Si eres justo has de tener tu Cruz porque Christo era la misma justicia y la tubo. Si eres penitente has de tener Cruz porque el buen ladrón era penitente y la mayor parte de su penitencia fue la Cruz. $\mathrm{Si}$ eres pecador has de tener Cruz, porque el mal ladrón era pecador $y$ estubo crucificado. Si eres Rey, si eres título has de tener tu Cruz porque Christo tenía sobre su Cruz este título: "Rex judeorum". Y asi si el Rey como el título estaban clavados en ella. En fin si tubiere voluntad de llebar la Cruz, la llebarás, porque Cyreneo no tenía voluntad de llebar la Cruz y se la hicieron llevar por fuerza. De suerte que o por acto de virtud o por remedio de necesidad no hay que pasar esta vida sin Cruz. La dicha está en saberla escoger y acertar en la elección" ${ }^{97}$.

Bajo esta concepción, resulta congruente que pese a peligros y dificultades esté deseoso de misionar, como pronto lo conseguirá:

"Yo acabé por noviembre mis estudios y aviendo echo las doctrinas en esta misión que se hizo en Manila, me señalaron por misionero de este pueblo - San Pedro, se entiende- que la mayor parte es de tagalos aunque ay mestizos, chinos, pamgasmanes y pampamgos. Luego me apliqué a la lengua, de suerte que aunque con mucho trabajo, pude confesar de Cuaresma, prediqué el Viernes Santo el pagtatangas o el descendimiento. Ya era de quince en quince días que les hago una plática, pues la dificultad de la lengua no permite que sea de ocho en ocho como es lo que avíame destinado para aprender la lengua sangleya para administral a los chinos, pero se descompuso. En las yslas de Pintados está la mayor parte de la Provincia y a más de los trabajos ordinarios a todos, padecen mucho con las continuas correrías de moros de aquellas costas, donde talan, roban, queman y cautivan. Ay remito la relación de los daños que han hecho en estos años en que han tenido que ofrecer a Dios nuestros padres. ¡Ay tanta mies y tanto que trabajar, que ay sugeto a cuyo cargo están siete u ocho mil almas a quienes ha de confesar, predicar, instruir y administrar los sacramentos! Y la mayor dificultad es que están repartidos en tres o quatro pueblos y así es menester andar continuamente. $Y$ algunos están a tal distancia que apenas en dos o más días se puede pasar de uno a otro caminando con viento recio y favora-

97 Biblioteca Nacional de Madrid (en adelante, B.N.), Manuscritos, Manuscrito 7020 , fol. $25 v^{\circ}-26$. 
ble. Añádase el trabajo de ser por mar los viages en unos parages muy peligrosos. Donde ha avido que no se ha podido conciliar en dieciocho meses por no poder salir de su ysla y en ella ni pasar por ella ningún sacerdote por las peligrosísimas travesías, corrientes rapidísimas y vientos furiosos y contrarios» ${ }^{98}$.

Él está orgulloso de la labor evangelizadora en general y más de la jesuita en particular, y del espeso trabajo que hay que realizar diariamente pues considera que los frutos son abundantes:

"Es singularísimo el esmero con que se cultiva esta cristiandad, que con poca diferencia, es de este modo rarísimo el doctrinero religioso que, si no está impedido, no diga misa todos los días, a ella asisten muchachos y muchachas y varias personas del pueblo por devoción. Acabada la misa rezan los muchachos el rezo cantándolo a coros. Los muchachos van después a una escuela, donde aprenden a leer, escribir, contar, rezar, policía y buenas costumbres. Las muchachas van a casa de la maestra, donde les enseñan lo que les pertenece. Allí están hasta las diez del día que se toca la campana: van a la iglesia, rezan y se van a sus casas. A las dos de la tarde vuelven a la iglesia, rezan y van a la escuela hasta que se toca la campana. Vuelven a la iglesia, donde rezan a coros el Rosario a la Santísima Virgen, cantan Salve, Alabado y salen en procesión cantando oraciones, hasta alguna cruz y de allí se van a sus casas. Rarísima será la casa en que de noche no se rece el Rosario y se diga la letanía y se cante la Salve. $Y$ yo he visto salir el Rosario por las calles y volver a la iglesia, cantando letanías en latín las mujeres, de memoria. Todos los sábados se canta la misa de la Santísima Virgen, asisten los congregantes, después baxa el padre y puesta una hermosa y pequeña imagen de la Señora en una mesita, el último sábado, se dan los santos del mes, con su sentencia en tagalo. Los demás cuenta el padre un exemplo de la Virgen en tagalo, con una breve exhortación, dice la letanía y otras oraciones, o se leen las reglas e indulgencias. El domingo reza todo el pueblo, chicos y grandes, las oraciones y doctrina en tagalo, hasta el modo de bautizar, para que todos lo sepan para una necesidad. En el coro se canta por la música la Gloria, el Credo y otras cosas. El padre predica en la lengua de la nación una plática moral y se lee el padrón de los feligreses para ver si faltan algunos y darles la penitencia. Por la tarde rezan los muchachos y baguntaos y dalagas; después baja el padre, pregunta y explica doctrina, reparte estampas y rosarios y bautiza niños. El sábado y el domingo canta la música en el coro la prima. Los domingos antes de empezar la misa, sale una procesión de muchachos con una imagen de la Virgen en un estandarte, cantando la doctrina alrededor del pueblo para juntar a la gente. Los sába- 
dos por la mañana canta toda la doctrina la gente moza; por la tarde reza el pueblo el Rosario en comunidad y cantan bellísimamente la Salve en tagalo y la música canta la del tiempo, descubierta la Virgen, y el padre canta la oración. Esto es lo que en general, casi con el mismo orden que va escrito, se hace en los pueblos todo el año, fuera de algunos, que añaden otras especiales devociones" 99.

Esto no le impide desde un inicio, pensar en la necesidad de proseguir la evangelización, de profundizar, de observar que tras la «diversión", campea el desconocimiento del verdadero Dios en las gentes de estas islas. Por eso expresa:

«Pero quiebra el corazón el ver que muchos son gentiles, otros moros, otros cismáticos, y aún los que son católicos tienen tan desfigurada la religión en sus costumbres que apenas les queda más que el nombre de christianos, de todas estas gentes el mayor golpe carga sobre nosotros» 100 .

Esta es la vida de misionero que aunque dura pretende llevar y en cierto modo llevó toda su vida el padre Pedro Murillo Velarde. Pero además de sus cualidades apostólicas sus superiores, ya en España, reconocieron en él su profunda capacidad intelectual y su viva inteligencia. Algo que la Compañia no pensaba desperdiciar. De este modo se le exigirá que termine sus estudios en leyes y cánones así como en teología, incluso estando ya en las islas y en ellas será representante, desde el inicio de su estancia en el Archipiélago, del potencial cultural de la Compañía de Jesús, frente a colegas religiosos, frente a autoridades civiles y eclesiásticas, frente a amigos y enemigos. $Y$ todo ello pese a las quejas del padre Murillo Velarde, quejas tenues y suaves que de vez en cuando se atreve a presentar o expresar:

"Remito - al Colegio de Alcalá de Henares- el acto que me mandaron tener y de que no me puedo escusar, por más que lo pretendí. $Y$ aviéndoseme insinuado que se dedicase a la Real Audienzia de Manila y

99 P. Murillo Velafde, Geographía Histórica de las Islas Philipinas, cit., pp. 39-41. Orgullo que también se percibe en el prólogo a su historia de la Compañia en Filipinas: «En esta historia de la Provincia de Philipinas verá el lector las maravillosas hazañas que han hecho sus misioneros, admirará las heroycas virtudes que han exercitado, las empresas difíciles que han conseguido, las dificultades arduas que han llanado, y los varones insignes que han cultivado esta distante viña, siguiendo a San Francisco Xavier a quien venera antesignano esta Provincia", Ibidem, Historia, cit., Prólogo.

100 A.P. T.S.I., E-2: 98, 13. Carta del padie Pedro Murilio Velarde, 1725. 
que pusiere algunas questiones de los dos Derechos para que pudieran argüir los oydores, executé todas las de Santo Thomás al título de Justitia et iure. Puse conclusiones canónicas, civiles y reales para que arguyesen los oidores, como lo hicieron por la tarde, en que ubo otros tres argumentos de Theología en la Cathedral, ante el obispo electo y comisario de la Ynquisiçión que dexaba de ser provincial de Santo Domingo. Puedo asegurar a vuestra reverencia que fue pesadísima para mí esta función, por no ser de mi genio y por ser al parecer con el fin que nos saca de nuestra Provincias. Pero puedo asegurar que es al contrario pues nunca es más firme la vocación de las Yndias que quando uno hase una total indiferencia por la hacer lo que le mandaron. $Y$ por falta en alguno de esta resignación se hallan descontentos y lo peor es que atribuyen a la Providencia lo que es defecto de ellos mismos $y$ ' en esto se han experimentado unos fines desgraciados y deprorables. A más de que estas funciones escolásticas son de mayor trabajo que por allá y no tienen el aplauso ni lucimiento que logran en esa Universidad, y ésta es otra causa del desconsuelo de algunos que vienen a Indias y especialmente a esta Provincia. Donde los talentos de cáthedra o púlpito tienen todo el trabajo que donde más y no tienen el lustre, aplauso y estimación que por allá. Pues aquí no ay más esfera para todas estas prendas que Manila. $Y$ ésta en ese asumpto es muy corta y sólo viene bien el que desde luego se hace cargo a sepultar sus talentos, aunque sean los mayores en todas las líneas y aplícase a trabajar puramente por Dios sin mezcla de respetos humanos, porque aquí no ay aliciente alguno de tejas abajo" ${ }^{101 .}$

La segunda característica de Pedro Murillo Velarde y Bravo, es su vocación de jurista. Dotado de una gran inteligencia, y animado de una curiosidad infinita, ejerce magistralmente el oficio de letrado, jurista, historiador, geógrafo y de escritor religioso. Murillo se siente sacerdote y misionero, pero por encima de otras dedicaciones culturales, no puede impedir sentirse jurista. Un jurisperito que no sólo actúa en el foro o en la cátedra sino que va a dar a la luz obras meritorias de derecho, insertas en las corrientes jurídicas de la Edad Moderna española, y dentro de ellas como un defensor de la revalidación del Derecho Regio, derecho marginado por mucho tiempo en las Universidades españolas a favor del Romano, Derecho Regio que combina incluso con el Canónico como en el caso del Cursus, lo que no tiene que sorprender pues, él es un canonista, y como señala Salvador Albiñana hablando sobre los estudios de Derecho en el siglo XVIII:

"En líneas generales puede señalarse que la voluntad antirromanista y nacionalista del despotismo logró imponerse en la facultad de cáno- 
nes, que los gobiernos borbónicos supieron hacer valer sus derechos inalienables -las regalías- a intervenir en asuntos de interés mixto, que afectaban tanto al Estado como la Iglesia, y que, por el contrario, en la facultad de leyes no lograron de modo satisfactorio imponer su deseo de que el estudio del derecho real tuviera entidad propia» ${ }^{102 .}$

Aunque su obra jurídica es de una calidad excepcional -y muy exitosa en cuanto a su divulgación- todo debe tomarse con cierta moderación. Su estilo, ya se ha dicho, está incardinado en la tónica literaria moderna española y es que cabe recordar dos cosas: una, su preparación inicial es esencialmente peninsular y pese a que siguió estudiando en Manila de modo oficial y privadamente toda su vida, Granada y sobre todo Salamanca lo debieron marcar. Dos, que la «literatura jurídica indiana -inclusa la filipina- no nace en el vacío ni en el aislamiento, sino dentro de una tradición cultural del "mos italicus" y en conexión con la formación universitaria y los géneros literarios propios de los reinos hispánicos, especialmente con el estilo de la ciencia jurídica castellana» ${ }^{103}$. Su calidad está fuera de toda duda y además crece si se recuerda su dificil y ocupada vida y que en Filipinas «los misioneros de Filipinas difícilmente podían dedicarse a actividades que requerian un tiempo y dedicación de los que no disponían. Por otra parte, el mercado de libros era inexistente, ya que el poder adquisitivo de los filipinos era escasísimo. En tales circunstancias, escribir resultaba arriesgado; imprimir una locura» ${ }^{104}$. Pese a esto, repito, se impone la moderación en el juicio sin poner en duda que fue un gran jurista e intelectual, por ejemplo Menéndez Pelayo lo calificó del menos regalista de los canonistas de su tiempo -cita que ha tenido mucho éxito en las aproximaciones a la vida de Murillo-, pero mientras que si bien era un partidario sincero del Rey, de la dinastía de Borbón y admiraba a reyes como Felipe $\mathrm{V}$, su regalismo no es extremo, es cierto, pero en cualquier caso debe ser entendido dentro de la tradición de lo que se ha venido a llamar el regalismo tradicional español que ya parte de la dinastía de los Austrias y que continúa aumentado y modificado

102 S. Albiñana, "Leyes y Cánones en la Valencia de la llustración", en Claustros y estudiantes. Congreso internaciona! de historia de las universidades americanas y españolas en la edad moderna. Universidad de Valencia, Valencia, 1989, volumen 1, p. 1.

${ }_{103}$ F. Tomás y VAliente, Manual de Historia del Derecho Español. Ediciones Tecnos, Madrid, 1990 , p. 344

104 P. Borges (dir.), Historia de la Iglesia en Hispanoamérica y Filipinas (siglos XV-XIX). Volumen II: aspectos regionales. Biblioteca de Autores Cristianos, Madrid, 1992, p. 745. 
con los Borbones, pero indudablemente no será nunca un extremista, no es un Macanaz, en este aspecto estará más en el xVII, quizá, que en el XVIII. Él no entra dentro del juego de llustración española más o menos radical. De hecho, con las reformas de las Universidades españolas del XVIII, en cuanto a lo que toca al Derecho Canónico -pensando en expandir el regalismo-, "circularon ampliamente manuales y tratados más o menos inspirados en el galicanismo (ya conocidos y que estaban en imprenta) -Zeyer Bernardo Van Espen (1646-1728) y Carlos Sebastián Berardi (1719-1768)" " ${ }^{105}$. Se prefieren los manuales de canonistas extranjeros a los de españoles, lo que era justificado por la Universidad de Alcalá «porque los autores de nuestro país habían sido poco cuidadosos en respetar los derechos de la Corona y las libertades de la Iglesia española, como habian sabido hacer, por ejemplo, los autores franceses" ${ }^{106}$. Y si el gran Menéndez Pelayo -pero no muy objetivo - tachaba a Murillo de escaso regalismo, los hechos y la sociedad de la segunda mitad del siglo XVIII parecen que lo tenían claro. Buscando las Universidades -en la reforma citada- nuevos manuales, la de Valladolid «al señalar los libros de texto decía del canonista español Pedro Murillo Velarde que era muy bueno, pero que no se podía aconsejar por el riesgo que puede ocasionar su estudio y los perjuicios que de su doctrina se pueden originar a las regalías" 107. Ahí queda la duda de dónde colocar a Murillo realmente. Su estilo es tradicional, pero inserta evidentemente el Derecho Real en su obra dándole una importancia sobresaliente frente al Derecho Romano, entonces perseguido por el Estado. Sus obras son claras y amenas, sin dejar la calidad y caer en lo vulgar. Muchos lo han exaltado como jurista. Ángel del Arco ya dio a la imprenta el parecer de López de Adam, no sólo él es el que lo admira como maestro. De hecho tuvo muchos discípulos que alcanzaron puestos de relevancia fuera y dentro de $\mathrm{Fi}$ lipinas. Un ejemplo es el del doctor don Domingo Neyra, catedrático de Instituta en la Pontificia y Regia Universidad de la Compañía de Jesús, abogado de los Reales Estrados, de los Presos del Santo Oficio y Secretario del llustrísimo señor Gobernador de la Filipinas y Presidente de su Audiencia. Se reconoce discípulo de hecho y de pensamiento del

105 A. Garcia-Gallo, El origen y la evolución del Derecho. Manual de Historia del Derecho Español l. Artes Gráficas y Ediciones, Madrid, 1979, p. 107.

106 A. Álvarez de Morales, La ilustración y la reforma de la Universidad en España del siglo XVIII. Ediciones Pegaso, Jaén, 1979, p. 154.

107 lbidem, p. 152, nota 239. 
padre Murillo Velarde, al que califica el 18 de diciembre de 1747 como «un sugeto, que después de aver lucido las primacias de sus estudios en diversos Colegios, y en el mayor de Cuenca en Salamanca, pasó el año de 23 a estas islas a ilustrar el firmamento de las letras con las luces de su magisterio, en Theología, Sagrados Cánones, que en dos tomos epilogó en consonacia del derecho Real de España y de Indias», pero «cuyos afanes han arrebatado más la admiración, por no haver perdido punto, instante, ni momento, que no ayan sido bien empleados en actos de verdadera y estricta religiosidad a beneficio de las Almas, en tan concertada alternación, que formando un perfecto círculo de sus tareas ha venido a consumar en menos de un año, todo lo que comprehende la extensión de todo un siglo" 108. Por tanto, Pedro Murillo Velarde: jurista misionero.

Es misionero, pero también indiscutiblemente es un jurisperito, nunca se olvide, $y$ es que en sus obras y escritos, inclusive las que tratan de materias tan diferentes como la geografía, la historia o sus sermones, siempre dejan por algún resquicio escapar su condición de un excelente y superior jurista ${ }^{109}$.

Es un jurista pero no cumo aquellos que criticaban ya los humanistas, como Erasmo ${ }^{110}$. Pedro Murillo Velarde no encuentra en la abo-

108 D. Neyra, «Parecer», en P. Murillo Velarde, Historia, cit., s.p.

109 A modo de ejemplo este párrafo que está extraído del «Sermón del Apóstol San Andrés o de los triumphos de la Cruz cifrados en las proezas de San Andrés", dice Murillo: «Es regla muy repetida entre los juristas que para entender las leyes es menester leer las rúbricas -lege rubricum si vis intelligere nigrum-. Fúndase esta regla en que al principio de cada ley se pone en resumen con letras roxas la ocasión, el tiempo y las circunstancias en que se hizo aquella ley y así se conoce en qué está su valor y fuerza. Bella regla para la doctrina que deseo brevemente explicaros. Tenemos en la Cruz el compendio de todas nuestras leyes, el resumen de todas nuestras obligaciones y según el apóstol San Pablo una cifra o rúbrica de la virtud y sabiduria de Dios... ", en B.N., Manuscrito 7020, fol. 22. Parece indudable que tenía siempre muy presente su condición de jurisperito y que incluso pensaba como tal.

110 Que decia: “Después de los médicos, los leguleyos ocupan el segundo lugar. Quizá deberia decir el primero, si no fuera porque los filósofos - me callaré mi opinión- se rien unánimente de ellos llamándoles asnos. Sin embargo la palabra de estos asnos decide los grandes y pequeños negocios. Sus latifundios aumentan, mientras el teólogo se estruja la mollera para sacar de ella la divinidad entera, tienen que comer altramuces, y no cesa en su lucha con las chinches y los piojos" E. DE RotTERDAM, Elogio de la Locura. Alianza Editorial, Madrid, 1984, p. 73. Y es que como Murillo atirma: «En lo que toca a los pleytos, es digna de especial noticia la sentencia de Christo: si alguno te pidiere por pleyto la túnica, dale la capa. En los pleytos sucede casi lo mismo que en el juego: que casi todos los jugadores pierden, por lo que se gasta en barajas, candelas y varatos. Los que seguramente ganan los pleytos 
gacía una forma de enriquecerse ni de ascender socialmente o de situarse por encima de los demás en un plano intelectual. Él cultiva esta disciplina —dejando a un lado su afición-como el estudio de las leyes que de una manera $u$ otra son de inspiración divina y que alimentan y gobiernan con justicia en el mundo. Pero además no se contenta -ni lo dejan-con regodearse en el derecho, ya sea real, canónico o común. Es además una persona que conoce su utilidad y que esta utilidad puede ser puesta en defensa de los desamparados, de su propia Orden, y en definitiva de la religión y la fe. Aunque esté predicando misiones, sirviendo como operario de indios o fungiendo como rector o procurador general, sigue siendo, quizás a pesar suyo, un jurista misionero. La Compañía dispondrá de sus servicios, el Estado también. Así sobre sus espaldas recae en buena medida sostener las cátedras de Cánones y Leyes concedidas a la primitiva universidad filipina, fundada por bula de Inocencio X, visada por la Audiencia de Manila el 11 de junio de $1648^{111}$, y en tiempos de Murillo en lastimosa decadencia. El grado de degeneración en que había quedado reducida dicha institución en Manila lo refleja el siguiente despacho del Consejo de Indias del 28 de marzo de 1735:

"En vista de una carta de la Audiencia de Manila y de memorial del procurador general de Yndias de la Compañia de Jesús (en que se pide se sirva Vuestra Majestad pasar ofizios con Su Santidad para que conzeda bulla al Colegio de San Ygnacio de aquella ciudad, a fin que en él se den grados mayores en las facultades de Cánones y Leyes) es de parezer - el Consejo de Indias - condeszienda Vuestra Majestad a esta instancia, en la forma que se expresa" ${ }^{112}$.

La antigua Universidad por cédula de 1718 desaparecía tras un largo declive y con ella las cátedras - "quedando suprimido el concepto de Universidad y la lectura de la Chátedra de leyes" como dice

son el abogado, que trampea, el juez, que soborna, y sobre todos el diablo que atiza. Este saca gran cosecha de odios, hurtos, chismes, falsos testimonios y perjurios con otros gages de mentiras, adulaciones, murmuraciones, dicterios y malas voluntades. Por esto pide la iglesia todos los días a Dios que apague las llamas de los pleytos. Muchas veces castiga Dios a estos pleiteístas en lo vivo de la codicia... ¡Escarmentad pleiteistas!», P. MURILLO VELARDE, Catecismo, cit., p. 50-51.

111 J. DE AlCAZAR, Historia de los Dominios Españoles en Oceania: Filipinas. Manila, 1895, p. 136.

112 A.G.I., Filipinas, leg. 96 . 
la mencionada instrucción-, pasado el tiempo mandose por otra de 26 de julio de 1730 -que se llevó a efecto en julio de 1733 por la Audiencia de Manila- que se reinstauraran: una de Instituta y otra de Sagrados Cánones. Dos en el Colegio de San Ignacio de los Jesuitas de Manila y otras dos en el de Santo Tomás de la Orden de Predicadores. La de Cánones de los jesuitas recayó en Murillo por orden de sus superiores y por invitación del poder civil, aunque no tenía esta cátedra ninguna asignación salarial, mientras que la de Instituta estaba dotada con 400 pesos al año y sería regida por un secular ${ }^{113}$.

La Compañía utiliza su saber jurídico en sus pleitos y disputas y ésta y el Estado hacen lo mismo en la docencia. Pero Pedro Murillo Velarde y Bravo lo utiliza igualmente al servicio de los menesterosos, como lo hizo - por ejemplo- en los conflictos de expropiación de tierras de Silán, en donde desesperados los nativos se levantan contra el representante de los abusos, Fray José de San Vicente, tras el siguiente memorial -escrito en tagalo en su momento en la villa de Silang a 28 de abril de 1745-:

"no tiene otro motivo el escrivir a vuestra reverencia esta carta sino dar los buenos días $j$ nos alegramos mucho de su buena salud y de su buena fortuna (padre reverendísimo) y que continúe para siempre ya que se cumplió el deseo intentado. Otrosí damos noticia a vuesa merced como mañana (si Dios fuere servido), día jueves, hemos de pasar todos los del pueblo a esas tierras nuestras que havéis ganado sin justicia (con respeto y fuerza de vuestra plata) y lo que hemos de hacer es echar abajo la casa que estáis tabricando... que esto no será despreciar la ley de Dios, ni bolberle las espaldas, ni tampoco al Rey nuestro señor" ${ }^{114}$.

Aunque a veces fue decisiva la intervención del jesuita Murillo al lado de los débiles nativos de Silang, confiando en la fuerza del Derecho, y despreciando la violencia, en otras ocasiones sólo el tiempo pudo volver a remediar las cosas y dejar la justicia restaurada.

Es más, él mismo no renuncia a la violencia, siempre que tenga un basamento justo acorde a la filosofía, el derecho y la religión. De esta manera cuando se refiere a hechos de armas los presenta descritos

113 B. Pazuengos, Carta, cit. Muchos elogiaron su labor al frente de cátedras en Manila, entre ellos el doctor don Francisco López de Adam, oidor decano de Manila y que al pasar a México como oidor, escribía en este sentido a Murillo.

114 A.G.l., Filipinas, Leg. 258, n. ${ }^{\circ} 68$. 
por lo general en términos heróicos e incluso recomienda su uso -el de la fuerza - con el objeto de dominar por completo las Islas Filipinas y acabar las zonas bajo las fuerzas rebeldes ya fueran musulmanas, protestantes o de otro cualquier tipo:

"No hay otro modo de remediar tantos daños sino conquistar estas isletas, que es fácil, si se toma con empeño y conducta” ${ }^{115}$.

Todo ello, claro está, justificado por un fin, un fin que no es otro bajo su pensamiento que traer a esas tierras la verdadera civilización, la cultura, la justicia, todos los beneficios que para él aporta la Monarquía española, y evidentemente y por encima de todo traer al seno de la verdadera religión a la población nativa. Una población a la que defiende - posiblemente en algunas ocasiones de forma tibia y siempre desde una evidente óptica paternalista - de adjetivos injustificados que han exparcido los pensadores europeos sobre los nativos, naturales y vecinos de las Indias y de las tierras meridionales. Así dice sobre los naturales y vecinos de las Islas que:

«Hay en Philipinas, como en todas partes, muchos tontos y necios, pero no faltan algunos ingeniosos y hábiles, de suerte que estudian gramática, philosophía y theologia, en que han hecho algún progreso, aunque no grande. En las cosas materiales suelen salir eminentes... Por facilidad que tienen los indios en aprender lo que ven, se dice, que los indios tienen el entendimiento en los ojos, pues quanto ven, tanto imitan ${ }^{116}$.

Por último, el tercer rasgo característico de nuestro autor, que se quiere destacar pues completa y se une a los otros dos, es su sentido del deber $y$ del trabajo. Es un hombre casi infatigable, pero también una persona perfectamente disciplinada, en estricta obediencia a su Compañía. Esto le permitirá sacar jugo a la inteligente labor de toda una vida, como jurista, como intelectual y como misionero. Los trabajos de la última actividad no le arredran, y más bien le satisfacen:

"Aunque yo me quedé en Manila, no me faltó mucho que trabajar pues con las tareas de estudiante se alternavan la de operario. Al salir de clase era preciso ir a confesar a muchos que esperaban: negros, mulatos, yndios, cafres, malabares y otra gente de este talle. Los domingos

115 P. Murillo Velarde, Geographia Histórica de las Islas Philipinas, cit., p. 76.

116 Ibidem, p. 37. 
iba con la doctrina a la Capilla Real, donde la explicaba y la Quaresma la prediqué a los soldados. A esto se juntaban misas de nueve, contadas al ir a las cárzeles, fuerzas y hospitales a predicar, confesar y ayudar a bien morir y sermones en nuestra Yglesia. De suerte que el número de gente que acude a nuestro Collegio es tal que no pueden dar a basto los operarios, aunque son muchos... Vienen de muchas lenguas y provincias a confesarse a nuestro Colegio y ay operario que confesaba al año a más de quinze mil personas. $Y$ esto en varias lenguas»" 117.

Ciertamente, la vida de misionero no era fácil:

“El pan ordinario que comemos en estas yslas es morisqueta, que es arroz cocido con agua, camiotes y varias rayzes. En Manila y aquí cerca ay trigo, pero fuera se reparte el bizcocho duro como pan vendito. No ay carnero, vino, aceyte, vinagre, nieve y casi nunca fruta, pero esto es lo que menos nos aflige porque suple con otras cosas la tierra. El martirio lento que aquí más suele atormentar es la soledad, pues en los pueblos apenas ay con quien tener por un rato conversación y así es preciso buscar la diversión en los libros que suplan la falta de comunicación, aquel tiempo en que no se está ocupado en los ministerios... Pero sy el misionero de Yndios vino verdaderamente llamado de Dios y no por particulares intereses, tendrá mucho que trabajar y estará muy consolado al ver lo bien plantada que está la religión» ${ }^{118}$.

En todos sus cargos seguirá siendo un misionero y jurista, por muy elevado que esté. Nunca olvidará sus armas intelectuales y nunca olvidará su misión, su verdadera Cruz, las Filipinas. Pero Pedro Murillo Velarde es una persona real, no una ficción, una persona compleja que evoluciona, que lucha por cambiar la realidad, la realidad que le tocó vivir por medio de la práctica evangelizadora y jesuita poniendo todas sus fuerzas a su servicio. Y Pedro Murillo Velarde es una persona que al final de su vida, como lo demuestran algunos de sus testimonios del autor, termina en cierta medida vencido, casi amargado -recuérdese la melancolía que lo llevo al otro mundo-, deseoso de seguir luchando pero sabiendo que la lucha es demasiado dura y que él difícilmente vencerá. Sobre sus queridas Filipinas, sobre el ardor de joven de su carta de 1725 , se le imponen ciertas realidades, ciertos criterios negativos que pese a que en algún modo los había compartido desde un inicio, siempre los había intentado contrapesar, superar. En 
los años finales de la década de 1740 y principios de la de 1750 , cuando él morirá, en esas fechas poco tenía que ver ya el pensamiento de Pedro Murillo Velarde con el de sus primeros años de misionero reflejado en la carta de Alcalá de Henares de 1725.

$Y$ es que el padre Pedro Murillo Velarde fue siempre un hombre critico ante el mundo, ante aquellas cosas que se oponían a su moral, a la ética, justicia y religión. Es crítico con la Historia y es crítico con la historia de su propio país, de la que por otra parte se siente muy orgulloso, orgulloso por ejemplo del hecho imperial -no sólo de la labor evangelizadora-, del hecho imperial en sí mismo. Pero eso nos es obstáculo para criticar ciertos aspectos de ese mismo hecho digno de su admiración:

"Con el cebo de las riquezas de Indias pasaban muchos españoles con una sed insaciable de odio y plata y no perdonaban a trabajos, ni fatigas con la dulce esperanza de enriquecer. Esta ansia intolerable les hizo insoportables a los indios, que ya no los juzgaban hijos del Sol y venidos del cielo, sino hijos del diablo, vomitados del infierno" ${ }^{119}$.

No obstante su actitud con el indígena está cargada de influencia eurocéntrica, no lo considera inútil por naturaleza, ya se ha visto su testimonio, pero desde su llegada mantiene por un lado la esperanza de llegar a él, de comprenderlo y de hacerse comprender y por medio de ello de convencerlo, cambiarlo y convertirlo, y por otro lado mantiene ciertos reparos, quizá no tan furibundos o extremos como los de otros, pero verdaderamente reparos negativos heredados que no mitigarán sino que aumentarán. Desde un inicio advierte la diversidad, la diferencia con él y con lo que él representa y la diversidad entre ellos mismos, entre los naturales y pobladores de las Filipinas. Y, si esto en la carta de Alcalá, en los comienzos de su existencia como misionero, lo describe de forma incluso alegre y atrayente, ya en su Geografía, las descripciones se atemperan:

"Las gentes que habitaban estas islas, quando la conquistaron los españoles, se distinguían en dos diferencias principales. Había naciones políticas, con su modo de gobierno, subordinación y policía, $Y$ otras que

119 P. MuRlelo Vel.ARDE, Geografía Histórica de la América y de las Islas adyacentes y tierras árcticas y antárcticas e islas de los mares del Norte y del Sur. Imprenta de don Agustín Gordejuela y Sierra, Madrid, 1752, p. 38. 
vivian, poco menos, como fieras en los montes. Políticos eran los tagalos, pampangos, llocos, Pangafinanes, Cangayanes, Camarines, Visayas y Mindaneros. Bárbaros eran los negros del Monte, los Zambales, los Tingües, los Manguianes, llayas, Igorrotes, Subanos, Manobos, Tagabaloyes y otros que hasta ahora o no están sujetos o no lo están del todo" ${ }^{120}$.

Esta percepción del nativo filipino, ya menos entusiasta, pese a las virtudes que según él posee, contiene más opiniones contrarias que favorables:

"Estos son los indios mirados por la superficie exterior de su fachada -acaba de comentar lo positivo-; pero entrando en lo interior de sus genios, propiedades y costumbres son un laberinto en que pierde el tino aún el más lince. Son de natural tímidos y suelen arrojarse a cosas de grande atrevimiento. Son naturalmente perezosos y flemáticos y para sus negocios son vivísimos y diligentísimos. Parecen ingenuos y sencillos en su aspecto y sus palabras y hay eminentes maestros para engañar y fingir. Debajo de su sencillez aparente ocultan un doble solapado disimulo. Yo creo que nunca se engaña el indio, si se atraviesa su interés. En sus pleytos y negocios son como moscas, que por más que los ojeen nunca se apartan de su demanda y así nos ganan y vencen, a lo menos por inoportunos. Los sangleyes dicen que el español es fuego, el indio agua y que agua mata fuego. No sienten agravio ni agradecen beneficio. Si les dan una cosa luego piden otra. No hay regla fija para construirlos, para cada uno es menester una nueva sintaxis, por ser anómalos» 121.

De esta concepción del nativo, incluso del criollo quizá, no escapan ni los más encumbrados:

"Los colegiales son de ingenio y capacidad, penetran en las facultades conforme a la aplicación, aunque acabados los estudios no hacen más progresos. Son lucidos en sus funciones y predican bien y el que menos repite con expedición su harenga. Se imprimen muchos sermones en que hay algo de florete y mucho de papel de estraza» ${ }^{122}$.

Resulta notorio que sus palabras no son muy favorables, pero en su aparente tono son moderadas, descriptivas, no exaltadas, que no vienen a agrandar ni a agravar lo pensado por otros escritores hispanos, incluso se permite ser un poco irónico, como lo es en el siguiente párrafo sobre el idioma español de los nativos:

P. Murillo Velarde, Geographía histórica de las Islas Philipinas, cit., p. 33. Ibidem, p. 38.

122 Ibidem, p. 53. Texto citado en parte, también, en P. BOrges (dir.), Historia, cit., p. 745. 
«Estando una hora en Tuley o Puente de Manila se verán pasar casi todas las naciones de Europa, Asia, América y África, se verán sus trajes $y$ se oirán sus lenguas. El prodigio es que todos estos para comunicar entre sí hablan en español. Pero, ¿cómo? Cada nación ha formado una gerigonza por donde se entienden. Yo oí un día un gran pleito entre un sangley, un armenio y creo que un malaber, todos hablaban en español y yo no entendí a ninguno por no haber estudiado entonces sus vocabularios. Verbi gracia, los chinos para decir alcalde, español y indio, dicen así: alicaya, cancia, juania» ${ }^{123}$.

Pese a todo, pese a sus opiniones, para él el indígena debe ser a toda costa defendido y se lamenta más de una vez que se incumpla la voluntad regia a la que fue siempre tan afecto:

\begin{abstract}
“Manda el Rey en todas sus leyes a los gobernadores y justicias que amparen a los indios. Pero sucede lo que a David, que mandando a Joab guardase a Absaloum, Joab le quitó la vida a lanzadas. Mientras que nos manda el Rey que los amparen, más los persiguen los gobernadores y alcaldes. ¿Quántas providencias se dan en su bien, se convierten en su daño? Pone el Rey para defenderlos alcaldes, protectores y abogados, y sucede a lo que a las palomas quando tomaron por protector al gabilán contra el milano, que se comía más el gabilán en una semana que el milano en un año. El alcalde los chupa, el abogado los chupa, el protector los chupa y aún hay otros y otros chupadores de todos estados y calidades. Buen campo tiene que labrar el misionero en defender su grey: le lastimarán las espinas y abraojos, pero se coronará de rosas y azuzenas... Así creo que esto es sólo para espíritus valientes» ${ }^{124}$.
\end{abstract}

El que sea afecto al Rey y a la Monarquía no le impide ser crítico frente a estructuras, formas de actuación e incluso políticos, a veces con juicios propios de juristas y pensadores políticos españoles de la Edad Moderna y similares a ellos. Por ejemplo, la crítica a los funcionarios o a determinadas carencias o profesiones es habitual en Murillo, como en otros autores, críticas a profesiones como la abogacía - ya quedó referida su opinión-o sobre los médicos y las carencias en sanidad en las Filipinas:

«En las religiones hay algunos cirujanos que pasan por médicos. $Y$, en fin, cualquier farandulier que viene de allende con título de médico tiene aquí facultad libre de matar con purgas y vomitorios. Porque la fa-

124 Ibidem, Cathecismo, cit., p. 287. 
cilidad o necesidad de los españoles los gradúa luego de galenos, cuando los debiera graduar de galeotes. Más útil fuera convertir una cátedra de Instituta en Medicina” ${ }^{125}$.

La diferencia en sus críticas frente a las de otros pensadores, en su contenido, es que más de una vez van con nombre y apellidos, no son corregidores, alcaldes $u$ otro tipo de cargos los juzgados en general, sino personas específicas, y personas a veces realmente importantes como podía ser un gobernador capitán general de las Islas Filipinas y no uno lejano en el tiempo, sino cercano a él, cuyas camarillas y partidarios todavía subsistian:

“El de 1739 le sucedió don Gaspar de la Torre -como gobernador de Filipinas-, y se puede llamar el Job de estas Islas, porque en su tiempo se atropellaban las desgracias. De todo fue gran parte su inacción, desconfiaba de todos, resolbía tarde y ejecutaba con lentitud. Sus costumbres eran de muy cristiano, mejor para tener llaves de un convento que el bastón de las Islas. Murió sin dejar ni amigos ni enemigos el año de $1745{ }^{126}$.

Sin embargo, redundando en lo mantenido, estas posturas se agrian, se extreman, Murillo Velarde, envejecido en su naturaleza y en su pensamiento, está en cierta forma en su interior realmente entristecido, casi regocijado en lo negativo. Así consta en su obra seguramente más personal, en donde se vierte en la imprenta su pensamiento íntimo, su desesperación, quizá, por una vida que consideraba que no había llegado a alcanzar sus objetivos, que no había vencido. Y es que en su Catecismo sostiene lo siguiente sobre la vida misionera y sobre su experiencia de tantos años en Filipinas, crudamente, casi desesperado, con ansias de dar a conocer sus sentimientos, unos sentimientos que ya no eran los de aquel novicio dispuesto a comerse el mundo, a evangelizar, a aprender costumbres e idiomas, a triunfar. El texto es un poco largo, pero merece la pena que se transcriba como colofón de estas páginas:

"Los misioneros, como dexando la patria, los parientes, los amigos, las comodidades y esperanzas de Europa, se destierran voluntariamente

125 Ibidem, Geographía Histórica de las Is/as Philipinas, cit., pp. 54-55. Este tema, aunque si transcribir el párrafo, es tratado por p. H. de la Costa, en The Jesuits, cit., p. 567 y ss.

126 Ibidem, p. 49. 
a la América, al África, al Asia, y al último término o rincón del Orbe, qual son las Philipinas. El sacrificio es mayor del que piensan los superficiales y especulativos que no han salido del rincón de sus casas, ni se han visto en los peligros, sustos y trabajos de mares y de tierras extrañas y gentes peregrinas... No tienen hora, ni de día ni de noche, libre, de que no los llaman a la sementera, a administrar los sacramentos, unas vezes con lluvia, otras con sol, que abrasa, y casi siempre por malos caminos. Ha de ser maestro, pastor y médico de sus almas y aún de sus cuerpos, tutor, curador, agente, abogado, mayordomo y aún esclavo de los indios y todo lo hará con gran fruto y mucho mérito, si en todo les da un buen ejemplo... Mucho es lo que se hace, pero es más lo que se padece. Ninguno, que no haya experimentado, puede hacer cabal concepto de esta verdad. ¿Quién puede explicar los peligros, sustos, incomodidades y trabajos de la navegación, quando se ve en este siglo que han perecido náufragos muchos misioneros? El país es destemplado con calores, con vientos, con aguaceros, con rayos tempestades y mil intemperies. Hay muchos incendios, temblores, animales ponzoñosos y mil sabandijas molestísimas y fieros animales. En Philipinas se anda continuamente sobre el mar, cuidando de los pueblos divididos en varias islas. En los ministerios estamos como en el limbo con poquísima noticia del mundo. Se padece necesidad de mil cosas. No hay médico, ni cirujanos, ni sangradores, ni boticas. La soledad de gente racional es grandisima, no hay con quien tratar, sino con los indios. Estos son muchos para nuestro trabajo, pocos para el alivio y rarísimos para el desahogo de la comunicación: el sacristán de una aldea de Europa fuera un Cicerón en el pueblo. No hay quien consuele una aflicción, no hay quien resuelva una duda, no hay quien quite un escrúpulo, y lo que es más, tal vez, ni aún quien nos socorra en un lance repentino con los sacramentos de la iglesia, por la distancia de los pueblos y por la dificultad de los caminos, por mar, o por tierra rodeados de mares, de ríos, de montes, de bosques, de despeñaderos y de lodazales y por aquí andamos toda la vida por socorrer esas almas. La dificultad de aprender la lengua o las lenguas del país en unos hombres de edad y hablarla continuamente es trabajo penoso y de bastantes escrúpulos. El tratar con indios y más indios, veinte, treinta o quarenta años es un lento y desolado martyrio. Es gente de tan irregulares propiedades que el que los trata más, los conoce menos, y los más experimentados dicen que sólo se pueden definir por varios contradictorios... Es gente ruda, ignorante, miserable y desdichada. Andan descalzos, su vestido es poco menos que desnudez, su comida es un poco de arroz cocido, raíces, frutas, algún poco de carne y en lo común un pescadillo, sin más especiería, regalos, ni salsas que algo de sal. En medio de su sencillez son vengativos y hay algunos crueles. Más de veinte y cinco jesuitas han sido muertos en Philipinas a sus manos. $Y$ el año de 46 nos mataron dos en un levantamiento y hay varios a quien han herido y querido matar. Muchos misioneros han perecido en aquellos mares y el año de 48 se ahogó el capellán de Marianas en un naufragio. El año de 43 huvo grandes temblores que arruinaron algunos pueblos y un monte se hundió más de cinquenta brazas. El de 49 
rebentó el volcán de la laguna de Taal, por seis bocas de fuego de azufre. En ocho días huvo más de cien temblores, algunos horribles y duraron más de un año. Se siguieron formidables tempestades de rayos y lluvias molestísimas. El genio del indio es diametralmente opuesto al europeo, por su rudeza, por su floxedad y falacia. En San Simeón Stelyta se tubo por gran penitencia el sufrir sin quitar las chinches que le molestaban. Qué será aguantar las chinches de los indios por 20 ó 30 años... A Isaias aserraron con sierra de madera y a nosotros nos matan los indios con chuchillo de palo. Macencio ataba un muerto con un vivo. Esto que siempre se ha considerado un tormento intolerable, es ordinario a los misioneros, que heridos de genio vivo, están atados a los indios de genio muerto. Si no derraman nuestra sangre, a lo menos nos la pudren, nos la corrompen y nos la queman... Así el que es llamado de Dios abraze con fervor esta empresa. La mies es copiosa y pocos respectivamente los operarios. En Philipinas hay novecientos mil christianos. Más de doscientos y nueve mil cultiva la compañía con grande mérito y trabajo. El misionero ha de ser como el pastor que describe nuestro redemptor, no como el mercenario, que sólo mira el interés. Que a los indios como a la grey de su destino, como la viña que debe cultivar y aún como la cruz y ecúleo que debe merecer. Es gente humilde, sencilla, miserable, pobre y abatida y en lo común obediente al ministro: más peca de ignorancia y de rudeza que de malicia. Todo esto nos debe mover como en realidad nos mueve a compasión y amor de estas gentes desvalidas que apenas tienen otro amparo que el misionero" ${ }^{127}$.

\section{CONCLUYENDO}

La diferencia de pensamiento entre las dos etapas vitales del autor es clara, y sin duda se debe a una lenta evolución -por otro lado similar a la que resulta de los testimonios de otros hombres dedicados en circunstancias parecidas a la evangelización-, motivada por los muchos sufrimientos y sobre todo por la soledad de un hombre que ve cómo fracasan muchos de sus primigenios ideales, cómo fracasa él mismo, cómo, al fin, el mundo que pretendió conocer y modificar lo ha vencido, vencimiento que viene a caballo sobre todo de la hiriente soledad que tanto sufre una persona de la naturaleza de Pedro Murillo.

Todo lo hasta aquí dicho no indica que renunciara a su misión, al contrario, como ya se percibe de las últimas líneas de su Catecismo, aquí transcritas, él persevera en la labor misionera. Por lo tanto, nadie

P. Muaillo Velarde, Catecismo, cit., pp. 282-286. 
salvo el misionero podrá defender en algo al nativo desprotegido -su principal campo de trabajo-, misioneros que protegen al nativo y que necesitan del Rey para protegerse ellos de los nativos:

“En Indias, a quienes se les encargan las provincias para la reducción de almas, tienen obligación de conocerlas, cuidarlas, asistirles y curarlas... Han de penetrar los montes, las cuevas, los bosques y los escobdrijos de los indios y de los cimarrones o montarazes, han de procurar de reduzir a los gentiles. Y porque ya no basta la honda del pastor, deben ir con el báculo del Rey, que es poderoso y alcanza mucho: esto es con escolta como mandan nuestras leyes, que hablando de los indios, dizen que aunque parezca que se pazifican y pidan que los predicadores vayan a sus tierras, sea con resguardo y prevención, pidiéndoles sus hijos que estén como rehenes" ${ }^{128}$.

$Y$ es que, finalizando, él fue un hombre de carne y hueso, ni mito ni ficción, y que, pese a todo, su disciplina y su perseverancia le permitieron ser un buen misionero, un buen jesuita y un buen jurista. $Y$ también le permitieron sacar a la luz numerosos trabajos en muchas y diversas ramas del saber siempre con una muy alta calidad. Basta recordar sus obras más significativas: como el "Manifiesto a favor de los Indios de Silán y San Mateo»; la «Relación de las fiestas que hizo el Colegio de Jesús de Manila en la canonización de San Stanislao Kostka y San Luis de Gonzaga"; "Modo práctico de entablar la doctrina christiana»; «Novena de Santa María Magdalena de París»; El Cursus luris Canonici; "La Historia de la Provincia de Filipinas de la Compañía de Jesús. Segunda parte que comprende los progresos de esta Provincia desde el año de 1616 hasta el de 1716»; La Greografía Histórica - publicada en parte y en facsímil por la Universidad de Granada-; el "Catecismo o instrucción christiana en que se explican los mysterios de nuestra Santa Fe. Y se exhorta a huir de los vicios y a abrazar las virtudes"; o por último su exitosa "Práctica de Testamentos en que se resuelven las cosas más frecuentes, que se ofrecen en la disposición de las últimas voluntades" ${ }^{129}$. Su mapas, otros sermones, su vida de San Francisco Xavier, el perdido comentario y adición al Diccionario de la Real Academia de Lengua, antes existente en la Biblioteca Nacional de Madrid, etc., aún hoy descansan en espera de al-

\footnotetext{
128 Ibidem, p. 162-163

129 C. Sommervogel, S.J., Bibliottèque de la Compagnie de Jésus. Lovaina, 1960, Tomo V.p. 1455-1458.
} 
guien que con la perseverancia del jesuita Murillo Velarde los introduzca en el mundo de los lectores y los estudiosos. Pedro Murillo Velarde y Bravo no fue un santo, fue un hombre de su época, con defectos y con virtudes, como un hombre más. Por lo tanto no se trata de hacer un nuevo panegírico de él, ni tampoco de utilizar algunos de sus escritos para convertirlo en un cruel reaccionario. Es un hombre con fuertes convencimientos morales y políticos enclavados más todavía en la corriente del siglo XVII español, en el que nació, que en las corrientes de cierto cambio del siglo XVIII, no es un ilustrado, lo que no incapacita ni su vida ni su obra. Fue de prodigiosa inteligencia, pero como todos, condicionado por su tiempo y por las frustraciones personales. Quizá, él que cifraba la felicidad del hombre en saber escoger su Cruz, temió al final de su vida haber equivocado la elección. Pero, en cualquier caso, gracias a su saber enciclopédico y a sus labores intelectuales y a sus escritos y libros, fue y se hizo inmortal y universal, desde las Filipinas, este jesuita natural de una lejana comarca del Reino de Granada. 

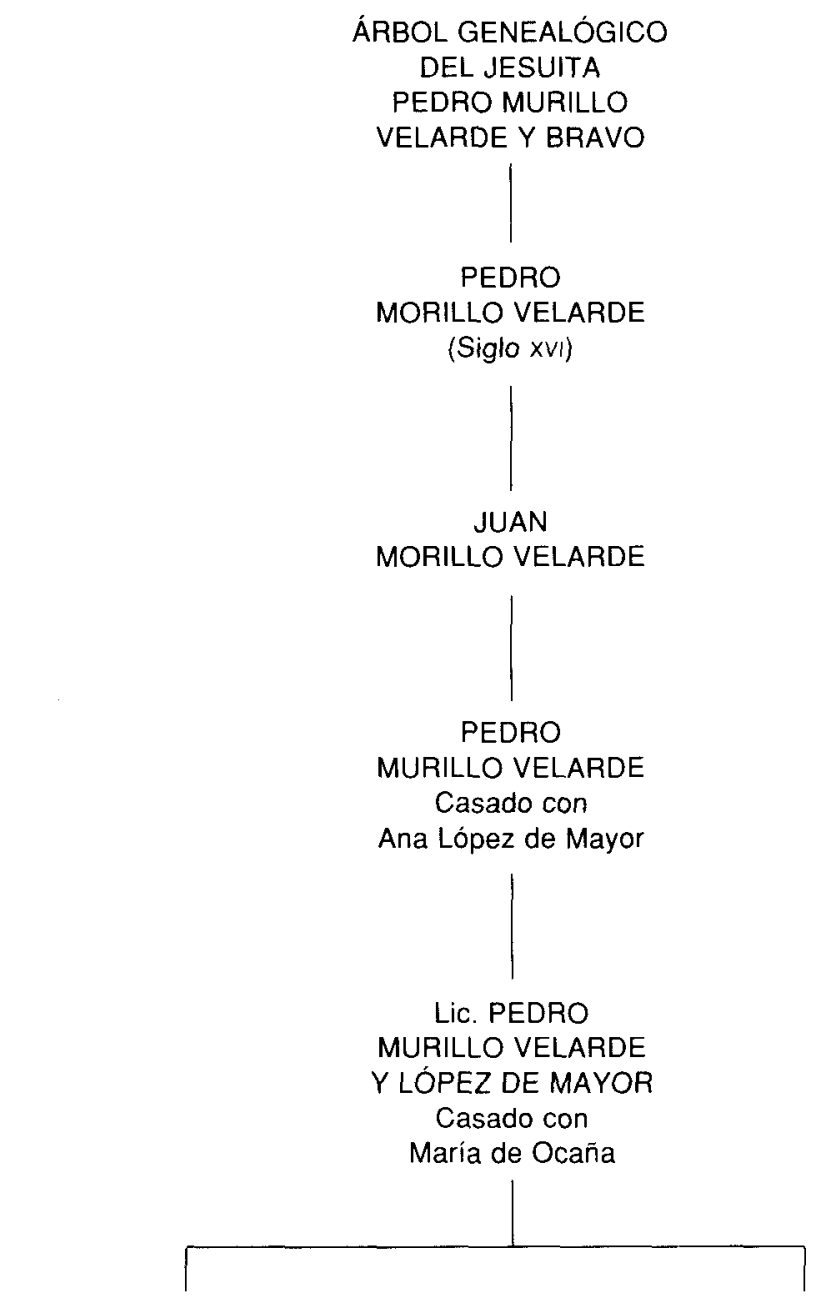

Andrés MURILLO VELARDE

Y OCAÑA

Obispo de Pamplona
Capitán JACINTO MURILLO

VELARDE Y OCAÑA

Casado con Magdalena Bravo

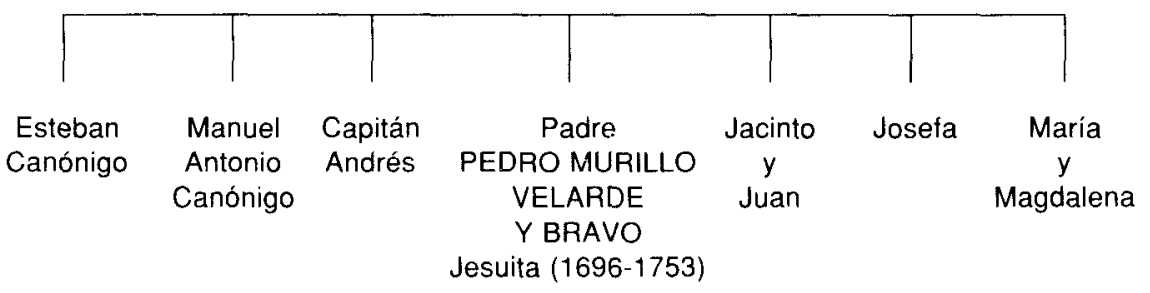

